\title{
Quantifying global terrestrial methanol emissions using observations from the TES satellite sensor
}

\author{
K. C. Wells ${ }^{1}$, D. B. Millet ${ }^{1}$, K. E. Cady-Pereira ${ }^{2}$, M. W. Shephard ${ }^{3}$, D. K. Henze ${ }^{4}$, N. Bousserez ${ }^{4}$, E. C. Apel ${ }^{5}$, \\ J. de Gouw ${ }^{6,7}$, C. Warneke ${ }^{6,7}$, and H. B. Singh ${ }^{8}$ \\ ${ }^{1}$ Department of Soil, Water, and Climate, University of Minnesota, St. Paul, Minnesota, USA \\ ${ }^{2}$ Atmospheric and Environmental Research, Inc., Lexington, Massachusetts, USA \\ ${ }^{3}$ Environment Canada, Downsview, Ontario, Canada \\ ${ }^{4}$ Department of Mechanical Engineering, University of Colorado at Boulder, Boulder, Colorado, USA \\ ${ }^{5}$ Atmospheric Chemistry Division, NCAR, Boulder, Colorado, USA \\ ${ }^{6}$ Earth System Research Laboratory, NOAA, Boulder, Colorado, USA \\ ${ }^{7}$ CIRES, University of Colorado, Boulder, Colorado, USA \\ ${ }^{8}$ NASA Ames Research Center, Moffett Field, California, USA \\ Correspondence to: D. B. Millet (dbm@umn.edu)
}

Received: 21 June 2013 - Published in Atmos. Chem. Phys. Discuss.: 23 August 2013

Revised: 30 January 2014 - Accepted: 5 February 2014 - Published: 13 March 2014

\begin{abstract}
We employ new global space-based measurements of atmospheric methanol from the Tropospheric Emission Spectrometer (TES) with the adjoint of the GEOS-Chem chemical transport model to quantify terrestrial emissions of methanol to the atmosphere. Biogenic methanol emissions in the model are based on version 2.1 of the Model of Emissions of Gases and Aerosols from Nature (MEGANv2.1), using leaf area data from NASA's Moderate Resolution Imaging Spectroradiometer (MODIS) and GEOS-5 assimilated meteorological fields. We first carry out a pseudo observation test to validate the overall approach, and find that the TES sampling density is sufficient to accurately quantify regional- to continental-scale methanol emissions using this method. A global inversion of two years of TES data yields an optimized annual global surface flux of $122 \mathrm{Tg} \mathrm{yr}^{-1}$ (including biogenic, pyrogenic, and anthropogenic sources), an increase of $60 \%$ from the a priori global flux of $76 \mathrm{Tg} \mathrm{yr}^{-1}$. Global terrestrial methanol emissions are thus nearly $25 \%$ those of isoprene $\left(\sim 540 \mathrm{Tg} \mathrm{yr}^{-1}\right)$, and are comparable to the combined emissions of all anthropogenic volatile organic compounds $\left(\sim 100-200 \mathrm{Tg} \mathrm{yr}^{-1}\right)$. Our a posteriori terrestrial methanol source leads to a strong improvement of the simulation relative to an ensemble of airborne observations, and corroborates two other recent top-down estimates (114-120 $\mathrm{Tg} \mathrm{yr}^{-1}$ ) derived using in situ and space-based measurements. Inver-
\end{abstract}

sions testing the sensitivity of optimized fluxes to model errors in $\mathrm{OH}$, dry deposition, and oceanic uptake of methanol, as well as to the assumed a priori constraint, lead to global fluxes ranging from 118 to $126 \mathrm{Tg} \mathrm{yr}^{-1}$. The TES data imply a relatively modest revision of model emissions over most of the tropics, but a significant upward revision in midlatitudes, particularly over Europe and North America. We interpret the inversion results in terms of specific source types using the methanol:CO correlations measured by TES, and find that biogenic emissions are overestimated relative to biomass burning and anthropogenic emissions in central Africa and southeastern China, while they are underestimated in regions such as Brazil and the US. Based on our optimized emissions, methanol accounts for $>25 \%$ of the photochemical source of $\mathrm{CO}$ and $\mathrm{HCHO}$ over many parts of the northern extratropics during springtime, and contributes $\sim 6 \%$ of the global secondary source of those compounds annually.

\section{Introduction}

Methanol is the most abundant non-methane organic compound in the troposphere, and a precursor of carbon monoxide, formaldehyde, and ozone (Singh et al., 1995, 2001; Tie et al., 2003; Millet et al., 2006; Duncan et al., 2007; Choi et al., 
2010; Hu et al., 2011). Methanol is produced in plants during cell wall growth (Fall, 2003), and appears to be emitted by most land plants (Fall and Benson, 1996). As a result, biogenic emissions are thought to constitute the largest fraction of the global methanol source (Millet et al., 2008a; Stavrakou et al., 2011; Guenther et al., 2012). Emissions of methanol thus represent an important chemical interaction between the biosphere and atmosphere.

Other sources of atmospheric methanol include biomass burning (Holzinger et al., 1999; Andreae and Merlet, 2001) and anthropogenic emissions (Holzinger et al., 1999; de Gouw et al., 2005; Hu et al., 2011), both minor terms in the global budget that can be important on regional scales. Methanol is also produced photochemically via peroxy radical permutation reactions (Tyndall et al., 2001), which provide a diffuse source most important in the remote atmosphere (Lewis et al., 2005). Observations in the ocean mixed layer imply that the marine biosphere is a large primary source of atmospheric methanol, but an even larger gross sink (Heikes et al., 2002; Williams et al., 2004; Carpenter et al., 2004; Millet et al., 2008a; Yang et al., 2013). Photochemical oxidation by the hydroxyl radical $(\mathrm{OH})$ is the other main sink for atmospheric methanol, followed by dry deposition to land. The overall atmospheric lifetime for methanol, accounting for gross ocean uptake, $\mathrm{OH}$, and deposition, is approximately 5-6 days (Millet et al., 2008b; Stavrakou et al., 2011).

Due to sparse long-term surface observations, the magnitude and distribution of global methanol sources is poorly constrained. Recent studies have found that current emission inventories lead to significant spatial and temporal model biases relative to in situ and satellite observations. Millet et al. (2008b) found that a net primary productivity- (NPP-) based emissions scheme developed by Galbally and Kirstine (2002), implemented in a chemical transport model (GEOS-Chem CTM), led to a methanol overprediction over the eastern US and the tropics that correlated with broadleaf tree coverage. Stavrakou et al. (2011) used methanol column measurements from the Infrared Atmospheric Sounding Interferometer (IASI) with the adjoint of the Intermediate Model for the Annual and Global Evolution of Species (IMAGESv2) CTM to constrain biomass burning and biogenic methanol emissions globally. They found that the Model of Emissions of Gases and Aerosols from Nature (MEGANv2.1; Guenther et al., 2012) predicted biogenic methanol emissions that were too high in the tropics and too low in more arid regions, such as the western US, central Asia, and northern Australia.

Hu et al. (2011) employed tall tower measurements in the US Upper Midwest in combination with the GEOS-Chem CTM to better understand the seasonal cycle of methanol emissions. They showed that methanol concentrations simulated by GEOS-Chem, driven by MEGANv2.0, peaked a month too late in summer compared to the observations (late July vs. June). This led, in turn, to an underestimate of the photochemical importance of methanol in early spring, when methanol emissions are high but isoprene emissions are still relatively low. Wells et al. (2012) used space-based measurements from IASI and from the Tropospheric Emission Spectrometer (TES) to demonstrate that this seasonal bias manifests across midlatitude ecosystems globally. They used the IASI data to derive an optimized set of emission factors as a function of leaf age, which resulted in higher emissions for new and old leaves and reduced emissions from growing and mature leaves relative to the standard MEGAN parameterization.

In this paper, we use a new two-year data set of spacebased tropospheric methanol observations from TES with the adjoint of the GEOS-Chem CTM in a global inversion to derive new constraints on terrestrial emissions of methanol. The analysis builds on our previous work using satellite observations to characterize the seasonality of methanol emissions in the extratropics (Wells et al., 2012) and on recent efforts applying the IASI sensor to investigate global emission fluxes (Stavrakou et al., 2011). We employ an ensemble of aircraft observations to evaluate the TES-derived emission estimates, and interpret the results in terms of underlying emission processes based on the methanol: $\mathrm{CO}$ correlations measured by TES. Finally, we explore the impact of our a posteriori methanol emissions on the photochemical production of formaldehyde and carbon monoxide in the global troposphere.

\section{TES methanol observations}

TES is an infrared Fourier transform spectrometer aboard EOS Aura, which has a local Equator overpass time of 13:45 and a $5 \times 8 \mathrm{~km}^{2}$ footprint at nadir (Beer et al., 2001). The first observations of methanol from TES were presented in Beer et al. (2008), and a detailed description of the methanol retrieval, sensitivity, and initial global results were given by Cady-Pereira et al. (2012). Wells et al. (2012) evaluated the TES retrievals using a suite of aircraft observations over North America, and found the two data sets to be consistent for retrievals with degrees of freedom for signal (DOFS) $>0.5$.

The methanol abundance is retrieved from TES measured spectra in the band ranging from 1032.32 to $1034.48 \mathrm{~cm}^{-1}$ using an optimal estimation approach (Rodgers, 2000). The retrieved methanol profile is related to the true profile $\boldsymbol{x}$ by

$\hat{\boldsymbol{x}}=\boldsymbol{x}_{\mathrm{a}}+\mathbf{A}\left(\boldsymbol{x}-\boldsymbol{x}_{\mathrm{a}}\right)$

where $\boldsymbol{x}_{\mathrm{a}}$ is the a priori profile and $\mathbf{A}$ is the averaging kernel matrix. Most TES methanol retrievals have DOFS < 1.0, so they contain at most one piece of information in the vertical. Because of this, we collapse the retrieved methanol profile into a single mixing ratio, called the representative volume mixing ratio (RVMR; Shephard et al., 2011). The RVMR $(\rho)$ is a measure of the methanol concentration over the vertical 
range where TES is most sensitive, and is calculated from the retrieved profile:

$\rho=\exp \left[\sum_{i=1}^{n_{\text {lev }}} \log \left(\hat{x}_{i}\right) w_{i}\right]$,

where $\hat{x}_{i}$ and $w_{i}$ are the retrieved mixing ratio and RVMR weighting function at level $i$. The weighting function is derived from a transformation of the averaging kernel, and reduces to a vector in cases where the information content of the retrieval is limited (DOFS < 1.0). The uncertainty of the methanol RVMR generally ranges from 10 to $50 \%$. The sensitivity of the retrieval to the true methanol profile peaks in the lower troposphere, typically between 700 and $900 \mathrm{hPa}$ (Cady-Pereira et al., 2012), making the TES data suitable for investigating surface emissions.

Here, we employ the GEOS-Chem 3-D CTM (see below) to interpret two years of global methanol observations from TES in terms of the constraints they provide on methanol emission processes. We restrict the analysis to retrievals over land and locations where the surface emissivity is greater than 0.92 , which results in 62209 retrieved profiles from 2008 and 2009. The number of TES observations per GEOSChem grid box (left panels) and their average DOFS (right panels) are mapped in Fig. 1 for the full data record and for the months of January and July. We see in Fig. 1a that TES provides extensive data coverage in the tropics but relatively few observations over North Africa, the Arabian Peninsula, and much of Australia. The latter are desert regions where the surface emissivity retrieval degrades in accuracy due to a strong and variable silicate absorption feature between 800 and $1300 \mathrm{~cm}^{-1}$. Errors in the emissivity retrieval can overwhelm the methanol signal over these areas. We also see in Fig. 1a and $\mathrm{b}$ that the number of observations and their corresponding DOFS decrease towards the poles, particularly in the Northern Hemisphere (NH). This mainly arises from the sparsity of observations during wintertime (Fig. 1c). During $\mathrm{NH}$ spring and summer, when methanol concentrations are elevated and there is greater thermal contrast between the land and atmosphere, we obtain more TES observations (and increased DOFS) at higher latitudes (Fig. 1e-f).

To compare the simulated and measured methanol profiles in the adjoint optimization, we sample the model at the time and location of each TES observation, interpolate the model profile to the TES vertical resolution, and apply the native TES a priori and averaging kernel using Eq. (1). The modelmeasurement difference is then used to compute the adjoint forcing profile in the inversion, as described later.
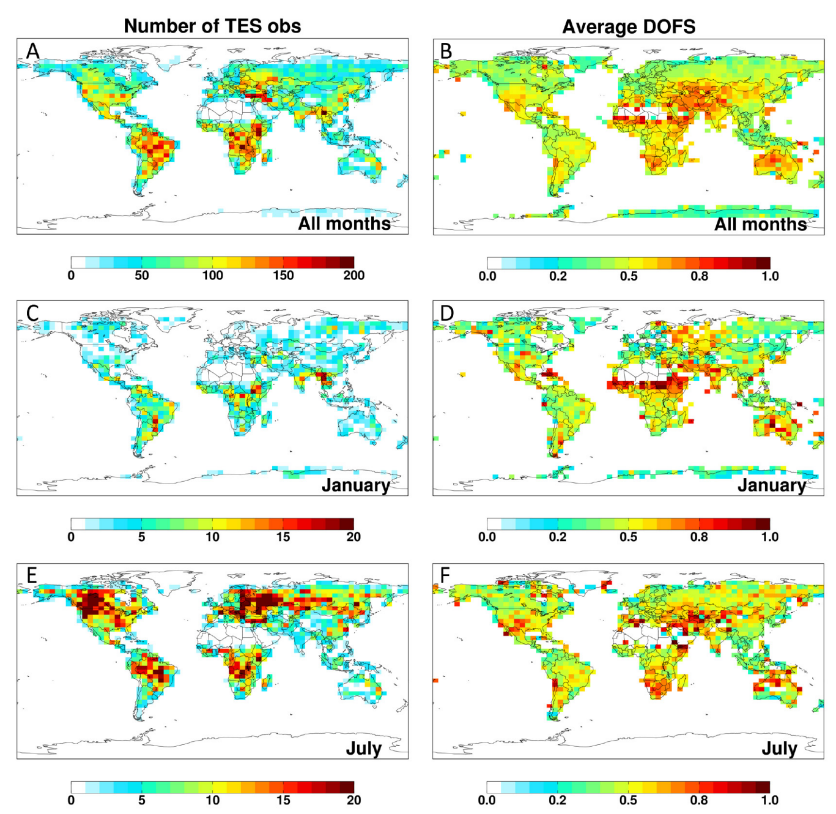

Fig. 1. TES sampling frequency and degrees of freedom for signal (DOFS) for methanol. Shown are the number of TES methanol observations in each $4^{\circ} \times 5^{\circ}$ GEOS-Chem grid box, and the average DOFS for those observations, during (A)-(B) all months of 20082009; (C)-(D) January 2008 and 2009; and (E)-(F) July 2008 and 2009.

\section{Methanol simulation in the GEOS-Chem CTM}

GEOS-Chem (http://www.geos-chem.org) is a global, 3-D model of atmospheric chemistry that uses GEOS-5 assimilated meteorological data from the NASA Goddard Earth Observing System. For this work we run the model at a horizontal resolution of $4^{\circ} \times 5^{\circ}$ and with 47 vertical levels extending to $0.01 \mathrm{hPa}$. Transport and emissions are calculated on 30 and 60 min time steps, respectively.

Methanol sources and sinks are computed in the model, following Millet et al. (2008b), with modifications described in Wells et al. (2012). Specifically, terrestrial biogenic emissions are estimated using the MEGANv2.1 algorithms (Guenther et al., 2012), with the seasonality in the extratropics updated to provide better agreement with atmospheric measurements (Wells et al., 2012), and using climatological monthly leaf area indices (LAI) from MODIS collection 5 (Yang et al., 2006). Biomass burning emissions are calculated based on monthly output from the Global Fire Emissions Database version 3 (GFEDv3; van der Werf et al., 2010). The methanol air-sea flux calculation derives the gas-phase and liquid-phase transfer velocities using the parameterizations of Johnson et al. (2010) and Nightingale (2000), respectively. Dry deposition of methanol includes reactive uptake by vegetation, as recommended by Karl et al. (2010). The resulting annual methanol source in our a priori simulation is $179 \mathrm{Tg} \mathrm{yr}^{-1}$, with $64 \mathrm{Tg} \mathrm{yr}^{-1}$ 
from terrestrial plants, $36.5 \mathrm{Tg} \mathrm{yr}^{-1}$ from secondary photochemical production, $8 \mathrm{Tg} \mathrm{yr}^{-1}$ from biomass and biofuel burning, and $4.5 \mathrm{Tg} \mathrm{yr}^{-1}$ from anthropogenic activities. Gross methanol emissions from the ocean surface contribute $66 \mathrm{Tg} \mathrm{yr}^{-1}$, but annual gross ocean uptake of $73.5 \mathrm{Tg} \mathrm{yr}^{-1}$ results in a net ocean sink of $7.5 \mathrm{Tg} \mathrm{yr}^{-1}$. Other sinks in the a priori simulation include oxidation by $\mathrm{OH}\left(70 \mathrm{Tg} \mathrm{yr}^{-1}\right)$, dry deposition to land $\left(26 \mathrm{Tg} \mathrm{yr}^{-1}\right)$, and wet deposition $\left(9.5 \mathrm{Tg} \mathrm{yr}^{-1}\right)$.

For this work we run the model for year 2008, and use a one-year spin-up to minimize any impact from initial conditions. To increase data coverage, we then compare the model output to TES retrievals for 2008 and 2009, under the assumption that interannual variability is smaller than other sources of model error (globally, terrestrial fluxes differ by less than $1 \%$ for the two years in the a priori simulation).

Figure 2 maps the terrestrial methanol emissions for December, January, and February (DJF) and June, July, and August (JJA) in the GEOS-Chem a priori simulation. Fluxes are high in the tropics, where emissions from terrestrial plants and biomass burning peak, and in the northern midlatitudes during the summer growing season. Our a priori emission estimate for terrestrial plants in 2008 is 35\% lower than the 99.6 $\mathrm{Tg} \mathrm{yr}^{-1}$ reported by Guenther et al. (2012) for the year 2000 , likely due primarily to the use of differing LAI and meteorological drivers. Maps of terrestrial biogenic emissions in the GEOS-Chem a priori simulation are shown in Fig. S1 (for DJF and JJA).

\section{GEOS-Chem adjoint}

We carry out an inverse analysis to quantitatively constrain global terrestrial methanol emissions on the basis of the TES data. The method involves minimizing a scalar cost function, $J(\boldsymbol{p})$, that quantifies the error weighted misfit of the model to the TES observations while accounting for prior knowledge:

$$
\begin{aligned}
J(\boldsymbol{p})= & \sum_{c \in \Omega}(\mathbf{H}(\boldsymbol{c})-\boldsymbol{y})^{T} \mathbf{S}_{\boldsymbol{y}}^{-1}(\mathbf{H}(\boldsymbol{c})-\boldsymbol{y}) \\
& +\gamma\left(\boldsymbol{p}-\boldsymbol{p}_{\mathrm{a}}\right)^{T} \mathbf{S}_{\mathrm{a}}^{-1}\left(\boldsymbol{p}-\boldsymbol{p}_{\mathrm{a}}\right) .
\end{aligned}
$$

Here, $\boldsymbol{p}$ is the vector of parameters (in our case, scale factors for terrestrial emissions) to be optimized, $\boldsymbol{p}_{\mathrm{a}}$ is their initial (a priori) value, $\boldsymbol{y}$ is a set of observations (in our case, TES methanol profiles), $\boldsymbol{c}$ is a vector containing the modelsimulated concentrations, $\mathbf{H}$ is an observation operator mapping from the model space to the observation space, $\mathbf{S}_{y}$ and $\mathbf{S}_{\mathrm{a}}$ are the observational and a priori emissions error covariance matrices, and $\Omega$ is the time and space domain of the observations. We also include a $\gamma$ term to help regularize the solution to this problem, given a lack of complete knowledge of the error statistics of the a priori emissions (Hansen, 1998). The maximum a posteriori solution for $\boldsymbol{p}$ is then given by the solution to $\min (J(\boldsymbol{p}))$.
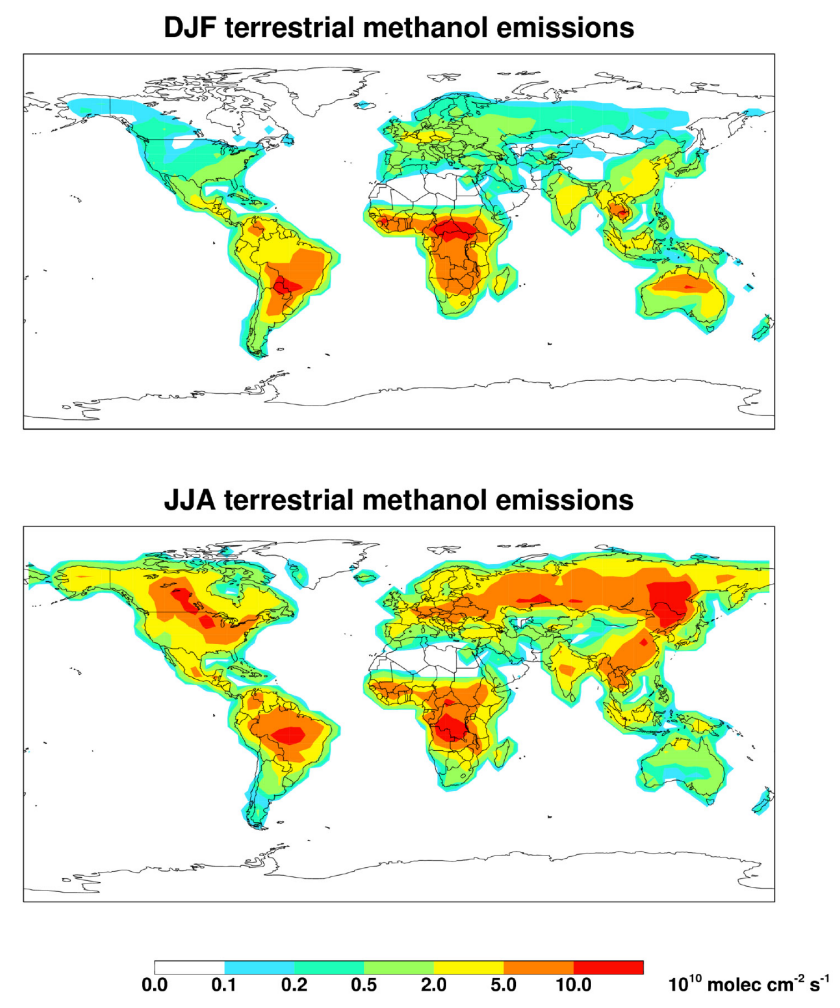

Fig. 2. December, January, February (DJF, top) and June, July, August (JJA, bottom) terrestrial methanol emissions in the GEOSChem a priori simulation (year 2008) from anthropogenic activities, biomass burning, biofuel burning, and terrestrial biota.

For this work we use the GEOS-Chem adjoint to solve for $\min (J(\boldsymbol{p}))$. The model adjoint computes the gradient of $J(\boldsymbol{p})$ with respect to methanol emissions, and employs a quasi-Newtonian optimization routine to iteratively converge to $\nabla_{\boldsymbol{p}} J(\boldsymbol{p})=0$ (Zhu et al., 1994; Byrd et al., 1995). Previous applications of the GEOS-Chem adjoint have included inverse modeling and sensitivity studies focused on aerosols (Henze et al., 2009; Kopacz et al., 2011; Wang et al., 2012), $\mathrm{CO}$ (Kopacz et al., 2009, 2010), $\mathrm{NH}_{3}$ (Zhu et al., 2013), and $\mathrm{O}_{3}$ (Zhang et al., 2009; Parrington et al., 2012), with additional studies developing complete error covariance constraints (Singh et al., 2011) and quantifying the impact of model error on inverse calculations (Jiang et al., 2011, 2013).

Our optimization employs two years of TES methanol profiles to derive terrestrial emissions at $4^{\circ} \times 5^{\circ}$, including the sum of contributions from anthropogenic activities, biofuel and biomass burning, and terrestrial plants. The TES data have greater coverage over the tropics (Fig. 1). Since the seasonal cycle of extra-tropical emissions in the model is already well constrained based on our earlier work (Wells et al., 2012) and TES data coverage is more limited at high latitudes, we perform here a seasonal inversion in the tropics (December-February, March-May, June-August, and September-November; hereafter DJF, MAM, JJA, and 

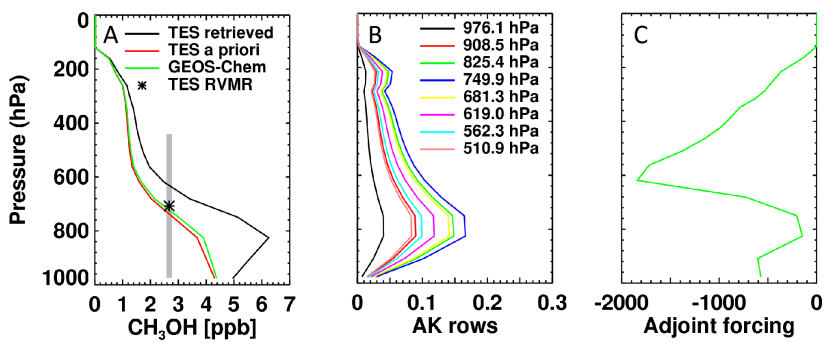

Fig. 3. Example of a TES methanol retrieval and corresponding adjoint forcing. (A) Retrieved methanol profile (black line), with the a priori profile (red line), the GEOS-Chem model profile with the TES a priori and averaging kernel applied (green line), and the TES representative volume mixing ratio (RVMR, black symbol). The shaded bar indicates the vertical range over which the RVMR applies, corresponding to the full width at half-maximum of the averaging kernel peak. (B) Rows of the averaging kernel for this retrieval, which has 0.78 degrees of freedom for signal (DOFS). (C) The corresponding adjoint forcing $\left(\nabla_{p} J(\boldsymbol{p})\right.$ for this example.

SON, respectively), defined as $23.5^{\circ} \mathrm{S}$ to $23.5^{\circ} \mathrm{N}$, and an annual inversion in the extratropics. We exclude retrievals over oceans, as these tend to have limited information content due to weak thermal contrast and low methanol abundance. The optimization routine bounds the solution so that the optimized emission scale factors are not less than zero, and the a priori emissions are assumed to have an uncertainty of $100 \%$ (with $\gamma=0.5$ ).

The observational error is calculated from the native TES instrument noise error covariance matrix (diagonal elements only); we apply a minimum threshold of $0.5 \mathrm{ppb}$ for this error as this corresponds to the TES limit of detection for the methanol RVMR (Cady-Pereira et al., 2012). We add to this an assumed $20 \%$ CTM error following Millet et al. (2012). An example of a TES retrieved profile, model profile (with TES averaging kernel and a priori profile applied), TES averaging kernel, and the corresponding adjoint forcing profile $\left(\nabla_{p} J(\boldsymbol{p})\right)$ with respect to the a priori emissions are shown in Fig. 3. The adjoint forcing in this case is strongest around $600 \mathrm{hPa}$, and is negative as the model concentrations are lower than the retrieved values for this example.

\section{Pseudo observation test of the adjoint method}

We performed a sensitivity analysis using pseudo observations to determine the spatial resolution at which the TES data can be expected to constrain surface emissions of methanol. The GEOS-Chem methanol fields were sampled according to the temporal and spatial sampling density of the two-year TES data set, and the native TES a priori profiles and averaging kernels then applied to the model output using Eq. (1) to generate pseudo-TES observations. We then carried out two global adjoint inversions using these pseudoTES observations: one with the a priori estimate for terres-

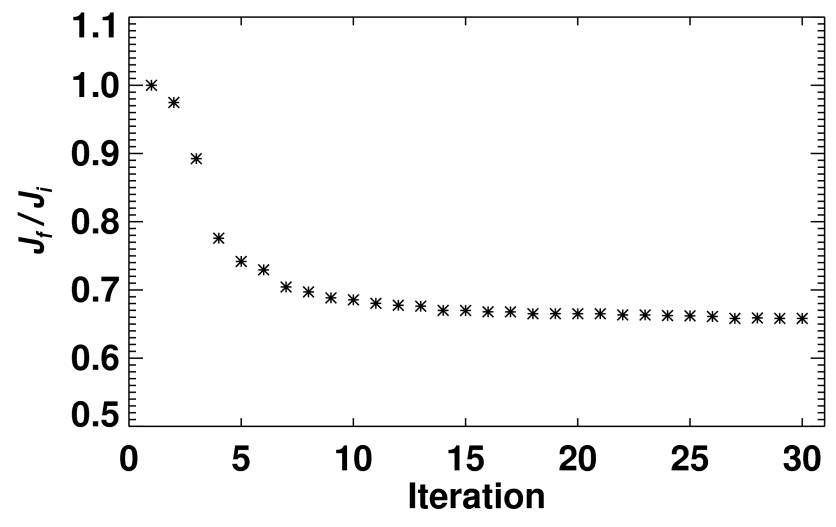

Fig. 4. Cost function evolution for the adjoint optimization using TES observations, plotted as the ratio of the final $\left(J_{\mathrm{f}}\right)$ to initial $\left(J_{\mathrm{i}}\right)$ value for each iteration.

Table 1. Pseudo observation analysis ${ }^{\mathrm{a}}$.

\begin{tabular}{lr}
\hline Region $^{\mathrm{b}}$ & Derived:actual emissions \\
\hline North America & $0.97,1.01$ \\
South America & $0.98,1.00$ \\
Central/Southern Africa & $0.99,1.00$ \\
Europe & $0.98,1.01$ \\
Southeast Asia/India & $0.97,1.01$ \\
Siberia & $0.99,1.01$ \\
Indonesia/Oceania & $0.96,1.03$ \\
\hline
\end{tabular}

${ }^{\mathrm{a}} \mathrm{A}$ posteriori annual terrestrial emissions are shown normalized to the actual emissions prescribed for the test inversion. The two numbers listed correspond to separate tests in which the a priori emissions were decreased $(0.5 \times)$ and increased $(1.5 \times)$, respectively, relative to the actual values. ${ }^{\mathrm{b}}$ Regions are as outlined in Fig. S4.

trial emissions perturbed downward $(0.5 \times)$ from their actual values, and one with the estimate perturbed upward $(1.5 \times)$. The native TES noise error for each corresponding pseudo observation was used as the observational error covariance matrix in each test. Ideally, the adjoint optimization would be able to recover the actual model emissions in each grid square; the degree to which this is not the case provides a measure of the uncertainty arising from the TES data coverage.

Figures $\mathrm{S} 2$ and $\mathrm{S} 3$ show the a posteriori emission scale factors for these test inversions. For both tests, there are a few model grid boxes with optimized scale factors that are higher or lower than 1.0, showing that the TES data sampling provides some limitation on our ability to retrieve emissions for any individual grid box. On the other hand, when we aggregate to larger regions, we find that the derived emissions are robust. Table 1 lists the optimized emissions, normalized by their true values and averaged over continental-scale regions (with boundaries as in Fig. S4). At this scale, the retrieved emissions for all regions are within $5 \%$ of the actual values. 

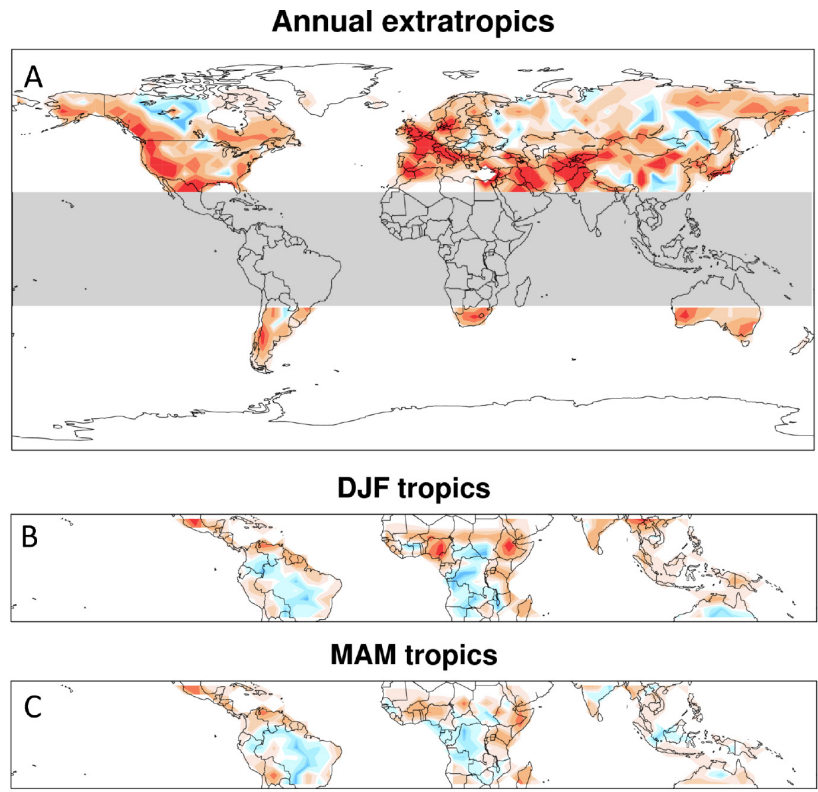

JJA tropics

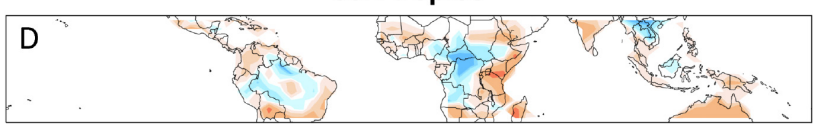

SON tropics

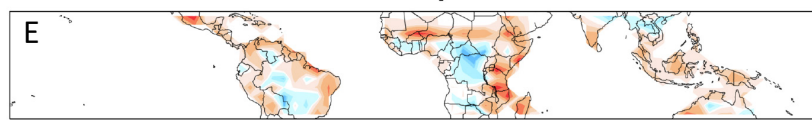

$\begin{array}{llllllllll}0.00 & 0.10 & 0.20 & 0.50 & 0.90 & 1.10 & 1.50 & 2.00 & 3.00 & 4.00\end{array}$

Fig. 5. Scale factors for the a priori terrestrial methanol emissions optimized on the basis of the TES observations. (A) Annual scale factors for the extratropics. (B)-(E) Seasonal scale factors for the tropics $(\mathrm{DJF}=$ December, January February; MAM = March, April, May; JJA = June, July, August; SON = September, October, November).

In the following section, we use these same regions for interpreting the terrestrial methanol emissions derived from the actual TES measurements.

\section{Optimized methanol sources}

Figure 4 shows the evolution of the cost function during the optimization of terrestrial methanol emissions using the actual TES observations, and Fig. 5 shows the corresponding scale factors for the a priori emission estimates. We converge on a solution after approximately 26 iterations, at which point additional iterations change the cost function by less than $0.5 \%$. The a posteriori cost function is reduced by $\sim 34 \%$ compared to the a priori value.

Figure 5 reveals some coherent and informative spatial patterns. Several of the regions where emissions are revised significantly upward are semi-arid, such as the western

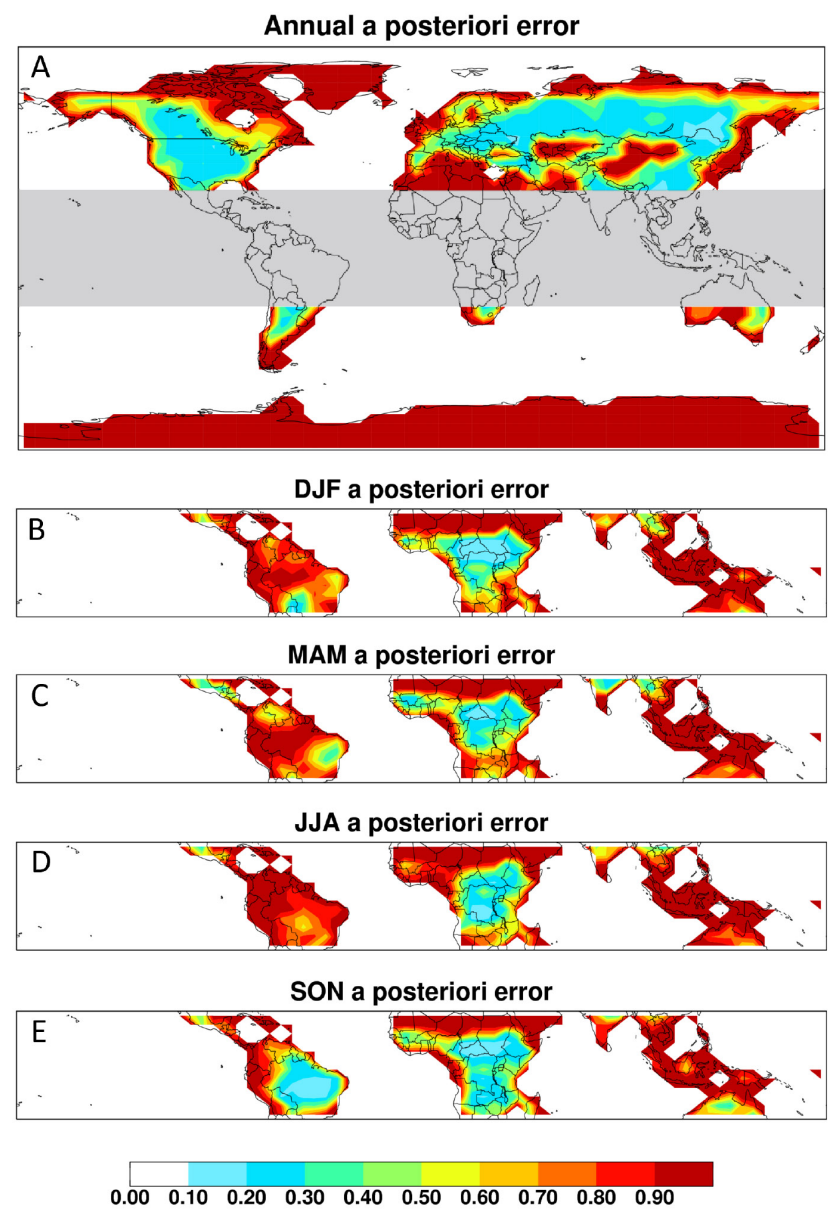

Fig. 6. A posteriori error estimate for the optimized methanol emissions (a priori error $=1.0$, i.e., $100 \%$ ). (A) Annual a posteriori error for the extratropics. (B)-(E) Seasonal a posteriori error for the tropics $(\mathrm{DJF}=$ December, January February; MAM = March, April, May; JJA = June, July, August; SON = September, October, November).

US and Mexico, the Iberian Peninsula, the Sahel, and central Asia. This is consistent with the findings of Stavrakou et al. (2011), who used IASI methanol retrievals to test MEGANv2.1 biogenic emissions in the IMAGESv2 model.

The optimization also leads to increased emission estimates for the eastern US, western Canada, eastern Africa, and South Africa. Emissions from Brazil are revised upward during SON. A particular region where emissions are scaled downward is central Africa (especially in JJA); emissions are also reduced in southeastern China, southeastern Russia, and portions of tropical South America.

We saw based on the pseudo-observation analysis in the previous section that the inversion is more robust across regional scales than it is for individual grid boxes. Figure 6 maps the a posteriori uncertainties for the actual inversion (calculated using a preconditioned BFGS algorithm; Bousserez et al., 2013), providing a more nuanced picture of 
the spatial constraints afforded by the optimization. We see in Fig. 6 that the a priori error is reduced by at least half throughout most of the northern midlatitudes, and by over $70 \%$ in much of Europe, Russia, East Asia, central Africa, North America, and Brazil (in SON). The DOFS for our inversion (which indicate the number of independently constrained emission variables) are 696.

Table 2 lists our optimized terrestrial methanol emission estimates for continental-scale regions around the world. Although there are parts of the tropics where emissions are reduced relative to the a priori estimate (Fig. 5), when aggregated to continental scales the a posteriori emissions are uniformly higher than the a priori. The global terrestrial methanol emission flux increases by $60 \%$ in the inversion, from 76 to $122 \mathrm{Tg} \mathrm{yr}^{-1}$ for the 2008-2009 period. This revised estimate supports two other recent top-down estimates of the global terrestrial methanol source: $114 \mathrm{Tg} \mathrm{yr}^{-1}$ for 2009 (Stavrakou et al., 2011) and $120 \mathrm{Tg} \mathrm{yr}^{-1}$ for 2004 (Millet et al., 2008a). Including gross ocean emissions of $66 \mathrm{Tg} \mathrm{yr}^{-1}$ and secondary photochemical production totaling $36.5 \mathrm{Tg} \mathrm{yr}^{-1}$, the total global methanol source increases by $25 \%$ as a result of the inversion. Relative emission increases are highest over Europe and North America (128-155\% increase over the a priori emissions) followed by Southeast Asia/India, Indonesia/Oceania, and Siberia. The smallest relative changes occur over central/Southern Africa and South America (Table 2).

Figure 7 shows TES RVMR annual time lines, averaged over 2008-2009 for the continental-scale regions mapped in Fig. S4. We also show time lines for Brazil and central Africa (with outlines as indicated by the green boxes in Fig. S4) to better assess the impact of the seasonal optimization in the tropics. Since the adjoint inversion was driven by the TES data, these comparisons are not an independent validation of the results, but instead provide a regional and seasonal comparison of the a priori and a posteriori simulations. Note that the optimization employed the full TES profile rather than just the RVMR values summarized in Fig. 7.

As we see in Fig. 7, the optimized simulation achieves significantly better agreement with the TES observations across these different global regions. The spring/summer model underestimate is reduced from $\sim 35$ to $\sim 10 \%$ over Europe, from $\sim 40$ to $\sim 15 \%$ over North America, and from $\sim 30$ to $\sim 10 \%$ over Siberia. Over South America, the bias is reduced from $\sim 30$ to $20 \%$ in SON. Some larger discrepancies do persist. The simulated methanol RVMRs over Southeast Asia/India, central/South Africa, and Indonesia/Oceania are still somewhat underestimated in the optimized simulation throughout the year (by 20-30\%), and wintertime concentrations are underestimated over North America, Europe, and Siberia (by $30-50 \%$ ). The latter behavior is probably due to the limited number of successful TES observations at high latitudes in wintertime. The rest of the seasonal cycle is well represented in the extratropical regions, supporting the updated seasonal cycle of methanol emissions derived by Wells
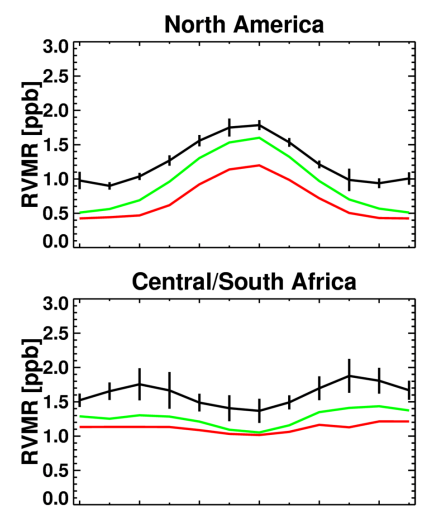

Southeast Asia/India

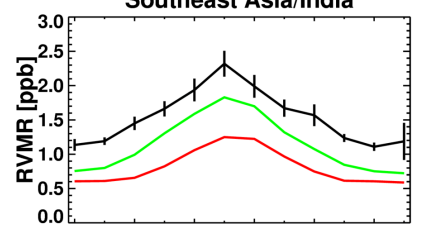

Indonesia/Oceania

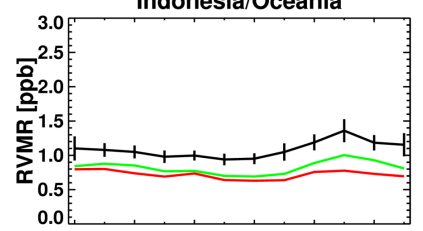

Central Africa

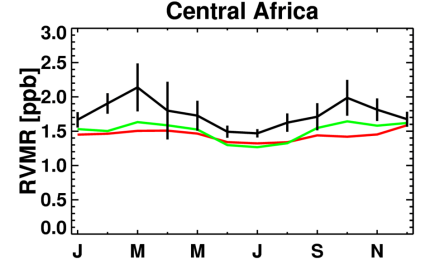

Fig. 7. Time lines of monthly-mean representative volume mixing ratio (RVMR) as measured by TES (black) and simulated by GEOSChem, averaged over the regions in Fig. S4. The vertical black lines correspond to the $\pm 95 \%$ confidence interval of the TES monthly means. The red line is the a priori GEOS-Chem simulation, and the green line is the a posteriori simulation with optimized terrestrial sources.

et al. (2012) that is used here, and the use of an annual inversion in these regions. In the tropics, the optimized simulation is better able to capture both the seasonal cycle and magnitude of observed methanol concentrations than is the a priori simulation.

\section{Sensitivity analyses}

Although we have included only terrestrial emissions in our state vector for optimization, other model processes, such as the methanol loss rate, might also contribute to the observed model-measurement discrepancies. In particular, a body of recent research has pointed to large inconsistencies between simulated and measured $\mathrm{OH}$ levels over high-isoprene, 
Table 2. Optimization of terrestrial methanol emissions based on the TES measurements.

\begin{tabular}{|c|c|c|c|c|c|c|c|}
\hline Region $^{\mathrm{a}}$ & $\begin{array}{r}\text { A priori } \\
\left(\mathrm{Tg} \mathrm{yr}^{-1}\right)\end{array}$ & $\begin{array}{l}\text { A posteriori } \\
\left(\mathrm{Tg} \mathrm{yr}^{-1}\right)^{\mathrm{b}}\end{array}$ & $\begin{array}{r}\text { Dep test } \\
\left(\mathrm{Tg} \mathrm{yr}^{-1}\right)^{\mathrm{c}}\end{array}$ & $\begin{array}{l}\text { Ocean tests } \\
\left(\mathrm{Tg} \mathrm{yr}^{-1}\right)^{\mathrm{d}}\end{array}$ & $\begin{array}{r}\text { Alt OH } \\
\left(\mathrm{Tg} \mathrm{yr}^{-1}\right)^{\mathrm{e}}\end{array}$ & $\begin{array}{r}\mathrm{p} 3 \mathrm{OH} \\
\left(\mathrm{Tg} \mathrm{yr}^{-1}\right)^{\mathrm{f}}\end{array}$ & $\begin{array}{r}\gamma \text { tests } \\
\left(\mathrm{Tg} \mathrm{yr}^{-1}\right)^{\mathrm{g}}\end{array}$ \\
\hline North America & 8.0 & 18.2 & 17.5 & $18.6,17.5$ & 18.9 & - & $17.9,18.0,17.8$ \\
\hline South America & 16.0 & 19.7 & 18.8 & $20.4,18.4$ & 18.4 & - & $19.3,19.4,19.1$ \\
\hline Central/Southern Africa & 22.5 & 28.1 & 26.9 & $28.6,27.0$ & 27.1 & - & $27.7,27.8,27.6$ \\
\hline Europe & 5.1 & 13.0 & 12.6 & $13.2,12.2$ & 13.3 & - & $12.5,12.7,12.3$ \\
\hline Southeast Asia/India & 14.0 & 25.4 & 24.3 & $25.9,24.1$ & 26.4 & - & $24.6,24.8,24.3$ \\
\hline Siberia & 3.5 & 5.3 & 5.1 & $5.3,5.2$ & 5.6 & - & $5.2,5.3,5.2$ \\
\hline Indonesia/Oceania & 6.0 & 9.1 & 8.9 & $9.8,7.9$ & 8.3 & - & $8.6,8.7,8.3$ \\
\hline Brazil & 5.7 & 6.3 & 6.0 & $6.5,6.1$ & 5.9 & 8.3 & $6.4,6.4,6.4$ \\
\hline Central Africa & 8.4 & 5.2 & 4.7 & $5.1,5.5$ & 5.1 & 6.7 & $5.4,5.4,5.6$ \\
\hline Global & 76 & 122 & 118 & 125,115 & 126 & - & $119,120,118$ \\
\hline
\end{tabular}

${ }^{a}$ Regions are as outlined in Fig. S4. ${ }^{b}$ Baseline inversion using standard model chemistry. ${ }^{c}$ Test inversion using alternate dry deposition sink (see text). ${ }^{\mathrm{d}}$ Sensitivity tests on the oceanic source/sink. The two numbers listed correspond to assumed seawater methanol concentrations of $70 \mathrm{nM}$ and $166 \mathrm{nM}$, respectively. ${ }^{\mathrm{e}}$ Test inversion using alternate global $\mathrm{OH}$ fields (see text). ${ }^{\mathrm{f}} \mathrm{p} 3 \mathrm{OH}$ is a parameterization that approximates the effects of $\mathrm{OH}$ recycling in high-isoprene, low-NO $\mathrm{O}_{\mathrm{x}}$ environments (see text). ${ }^{\mathrm{g}}$ Sensitivity tests of the a priori constraint. The three numbers listed correspond to fluxes derived using $\gamma$-values of $1.0,0.01$, and 0 , respectively.

low- $\mathrm{NO}_{\mathrm{x}}$ environments such as tropical forests (Lelieveld et al., 2008; Kubistin et al., 2010; Pugh et al., 2010; Stone et al., 2011). We performed a suite of sensitivity runs to assess the degree to which such uncertainties in model $\mathrm{OH}$ are likely to affect our derived emission fluxes. First, we repeated the inversion using global oxidant fields from a different version of GEOS-Chem, corresponding to a $6.4 \%$ lower global OH burden than the standard simulation (Millet et al., 2012). Next, we implemented a parameterization (denoted $\mathrm{p} 3 \mathrm{OH}$ ) that has been proposed by Stone et al. (2011) to approximate $\mathrm{OH}$ recycling during isoprene oxidation under low- $\mathrm{NO}_{\mathrm{x}}$ conditions (assuming that $3.0 \mathrm{OH}$ radicals are produced for each $\mathrm{OH}$ radical lost to isoprene).

Table 2 gives a summary of the inversion results for these sensitivity runs. The a posteriori emissions are very similar for the inversions using the two alternate $\mathrm{OH}$ fields derived using standard model isoprene chemistry. The $\mathrm{OH}$ recycling tests do impact the optimized fluxes to a degree in the tropics. Over central Africa, optimized emissions for the $\mathrm{p} 3 \mathrm{OH}$ simulation are $29 \%$ higher than they are when the standard model chemistry is used in the inversion. Over Brazil, optimized emissions are about $32 \%$ higher for the $\mathrm{p} 3 \mathrm{OH}$ simulation.

Mao et al. (2012) argue that, to some extent, measurement uncertainties may have contributed to reported observationmodel $\mathrm{OH}$ discrepancies in forest atmospheres. As such, we take the $\mathrm{p} 3 \mathrm{OH}$ parameterization as an $\mathrm{OH}$-recycling upper limit, and conclude that current uncertainties in low- $\mathrm{NO}_{\mathrm{x}}$ isoprene chemistry likely lead to at most a $30 \%$ uncertainty in our derived tropical methanol emissions. Likewise, Table 2 shows that use of the alternate global $\mathrm{OH}$ fields leads to at most a $10 \%$ change in our derived continental-scale methanol emission fluxes.

We also assessed the sensitivity of our results to model treatment of the two other major methanol sinks: dry deposition to land surfaces and oceanic uptake. In the first case, we reduced the reactive uptake coefficient for methanol from 1.0 to 0.5 (Karl et al., 2010) and repeated the inversion. This slightly reduced the optimized emissions nearly everywhere due to the diminished deposition sink. Changes were largest over central Africa $(\sim 10 \%$, due to the dense vegetation in this region); all other regions exhibited changes of less than $5 \%$.

For the oceanic uptake test, we varied the assumed methanol seawater concentration in the model $(118 \mathrm{nM})$ by $\pm 41 \%$, based on the standard deviation of observed values from Williams et al. (2004). This is also broadly similar to the range of variability measured recently by Beale et al. (2013). We find that assuming a seawater methanol concentration of $70 \mathrm{nM}$ increases the estimated net global oceanic sink to $\sim 15 \mathrm{Tg} \mathrm{yr}^{-1}$; an assumed concentration of $166 \mathrm{nM}$ leads to a global oceanic source and sink that are roughly in balance. These net global fluxes are both within the range of recent estimates (Millet et al., 2008a; Stavrakou et al., 2011; Beale et al., 2013; Yang et al., 2013). Inversions carried out under these two scenarios lead to optimized emissions that differ from the base case by less than $5 \%$ in regions outside the tropics, but by up to $15 \%$ over Indonesia/Oceania. Model assumptions related to the air-sea exchange of methanol thus have a larger impact on the inversion in regions with terrestrial emissions in close proximity to the ocean.

We also tested the extent to which our a priori constraint impacts the optimized emissions. In addition to the baseline inversion with $\gamma=0.5$ (and overall a priori uncertainty $=100 \%$ ), we performed three sensitivity inversions with the regularization parameter set to $1.0,0.01$, and 0 . The first two values correspond to overall a priori uncertainties of $\sim 70 \%$ and $\sim 700 \%$, respectively, while the third case contains no a priori constraint. The results indicate that our continental-scale emission fluxes are robust to assumptions regarding the a priori constraint. Indonesia/Oceania and 
central Africa exhibit the greatest sensitivity, with the a posteriori continental emissions differing by $\sim 8-10 \%$ between the baseline analysis and the no-constraint case; all other regions exhibit changes of $5 \%$ or less.

\section{Evaluation of optimized methanol sources using aircraft data}

In this section we use an ensemble of in situ measurements from recent aircraft campaigns to evaluate our new top-down estimates of terrestrial methanol emissions derived using TES. The aircraft campaigns include the International Transport and Chemical Transformation of Anthropogenic Pollution, ITCT-2K2 (2002; Parrish et al., 2004) and ITCT-2K4 (2004; Fehsenfeld et al., 2006); Megacity Initiative: Local and Global Research Observations, MILAGRO (2006; Singh et al., 2009); Intercontinental Transport Experiment-Phase B, INTEX-B (2006; Singh et al., 2009); the second Texas Air Quality Study, TexAQS-II (2006; Parrish et al., 2009); Arctic Research of the Composition of the Troposphere from Aircraft and Satellites, ARCTAS (2008; Jacob et al., 2010); and Aerosol, Radiation, and Cloud Processes affecting Arctic Climate, ARCPAC (2008; Brock et al., 2011). Because the TES observations employed here are for 2008 and 2009, we compare the aircraft data to a priori and a posteriori model simulations for 2008 sampled at the time-of-year and location of the aircraft observations.

Figure 8 shows campaign-average vertical profiles of methanol over land, measured aboard the aircraft and simulated by GEOS-Chem before and after optimization. The a priori emissions result in a significant model underestimate across North America, particularly in the boundary layer. The optimization leads to a strong improvement in the model-measurement comparisons across the ensemble of campaigns, with the observed profiles generally wellcaptured in the a posteriori simulation. In a few locations, the low bias is not entirely removed by the inversion. In particular, elevated boundary layer concentrations measured over the western US during INTEX-B and ARCTAS are not captured by the model. These campaigns both featured sampling over the California Central Valley and the Los Angeles area, where recent studies have found very high boundary layer concentrations of methanol (Warneke et al., 2010). High alcohol emissions from agricultural processes such as the fermentation of livestock feed have also been reported in this region (Howard et al., 2010; Malkina et al., 2011). Likewise, a residual low model bias is seen relative to the TexAQS-II measurements over Houston and the MILAGRO-C130 observations over and near Mexico City, probably because the flight data are heavily influenced by individual plumes that are not resolved at the $4^{\circ} \times 5^{\circ}$ model resolution. The DC8 observations during MILAGRO, representing more regionalscale outflow from Mexico City, are in good agreement with the optimized simulation. The ARCTAS measurements over

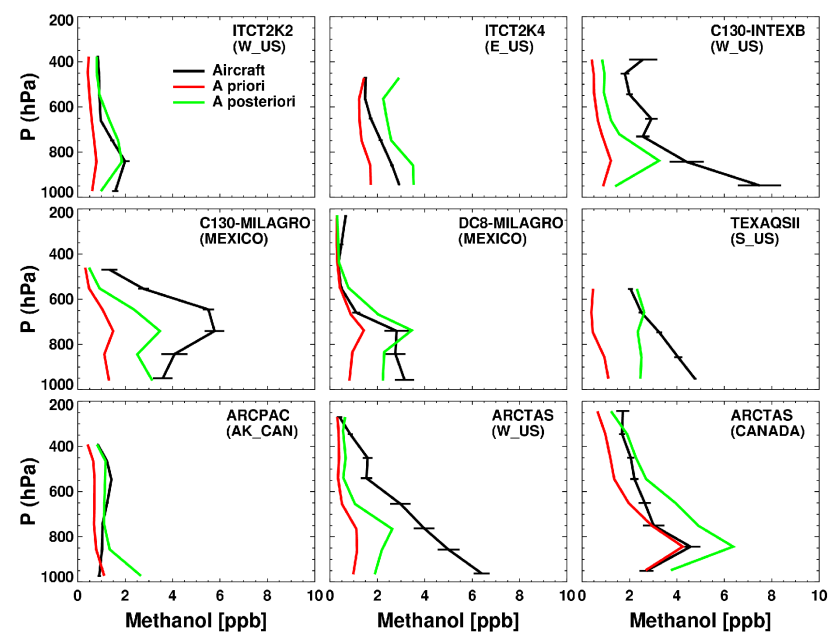

Fig. 8. Vertical profiles of methanol concentrations over North America. Each profile represents a campaign average over the region specified in the panel. Aircraft measurements are shown in black with the $\pm 95 \%$ confidence limits for each vertical bin indicated by the horizontal bars. The red line is the a priori GEOS-Chem simulation, and the green line is the GEOS-Chem simulation after a posteriori scaling factors have been applied.

Canada are overestimated by the optimized simulation within the boundary layer, but the two are in good agreement aloft.

Figure 9 shows marine methanol profiles for the above campaigns in which there was significant sampling over ocean. As before, the source optimization significantly improves the model agreement with the aircraft measurements throughout the vertical profile. The high free tropospheric methanol concentrations observed during INTEX-B over the eastern Pacific (C130 aircraft) are not captured by the model. A similar discrepancy was also noted by Stavrakou et al. (2011) relative to the IMAGESv2 CTM following an inversion using IASI data. Uncertainties in the Pacific source/sink of methanol could play a role here. On the other hand, our a posteriori simulation agrees well with other data sets over the Pacific and the Atlantic Oceans (Fig. 9), capturing the abundance of methanol for continental inflow to and outflow from North America.

\section{Characterizing source contributions based on TES methanol : CO correlations}

Our adjoint inversion optimized terrestrial methanol emissions as the sum of contributions from biogenic, biomass burning, and anthropogenic sources. In this section, we use methanol:CO correlations measured by TES to help interpret our inversion results in terms of specific source contributions. We select for the analysis regions that show significant differences between the a posteriori and a priori methanol emission estimates (Fig. S4). For the TES observations within each of the selected regions, we 


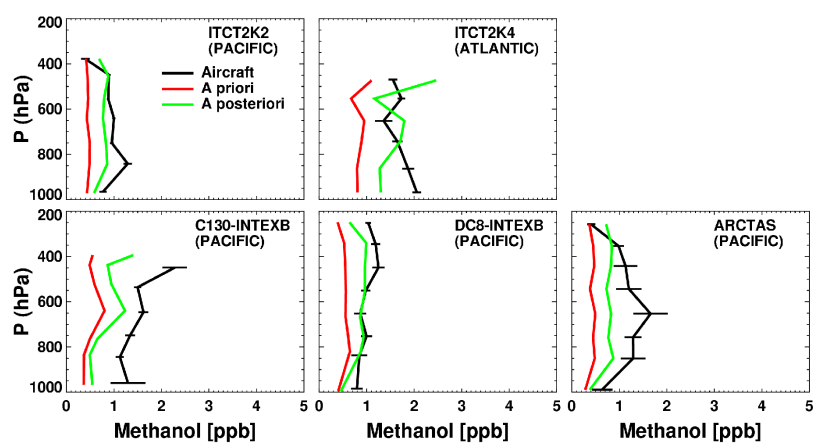

Fig. 9. Vertical profiles of methanol concentrations over ocean. Each profile represents a campaign average over the region specified in the panel. Aircraft measurements are shown in black with the $\pm 95 \%$ confidence limits for each vertical bin indicated by the horizontal bars. The red line is the a priori GEOS-Chem simulation, and the green line is the GEOS-Chem simulation after a posteriori scaling factors have been applied.
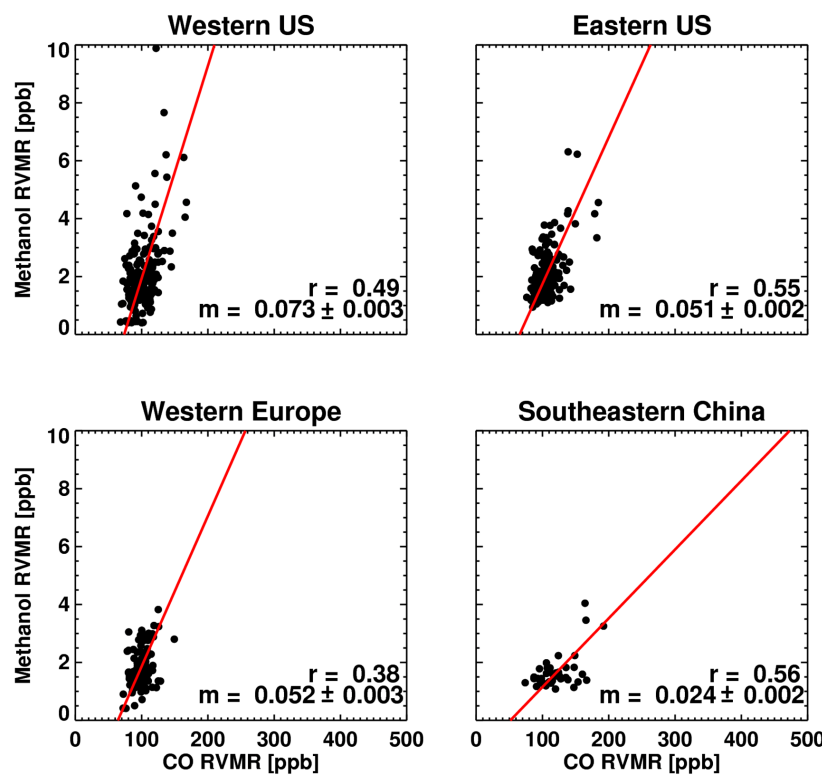

Fig. 10. Extratropical methanol: $\mathrm{CO}$ correlations as measured by TES during June-August. Regions are as outlined in Fig. S4. The TES CO RVMR is calculated by applying the TES methanol RVMR weighting function to the retrieved $\mathrm{CO}$ profile. Slopes are calculated using reduced major axis regression.

construct a methanol: CO correlation using methanol RVMR values and $\mathrm{CO}$ pseudo-RVMR values. The latter are computed by applying the TES RVMR weighting function for methanol to the corresponding retrieved $\mathrm{CO}$ profile using Eq. (2); this approach ensures consistent vertical weighting for both $\mathrm{CO}$ and methanol.

Figure 10 shows methanol: $\mathrm{CO}$ correlations measured by TES over the western US, eastern US, western Europe, and southeastern China (region boundaries are given in Fig. S4).
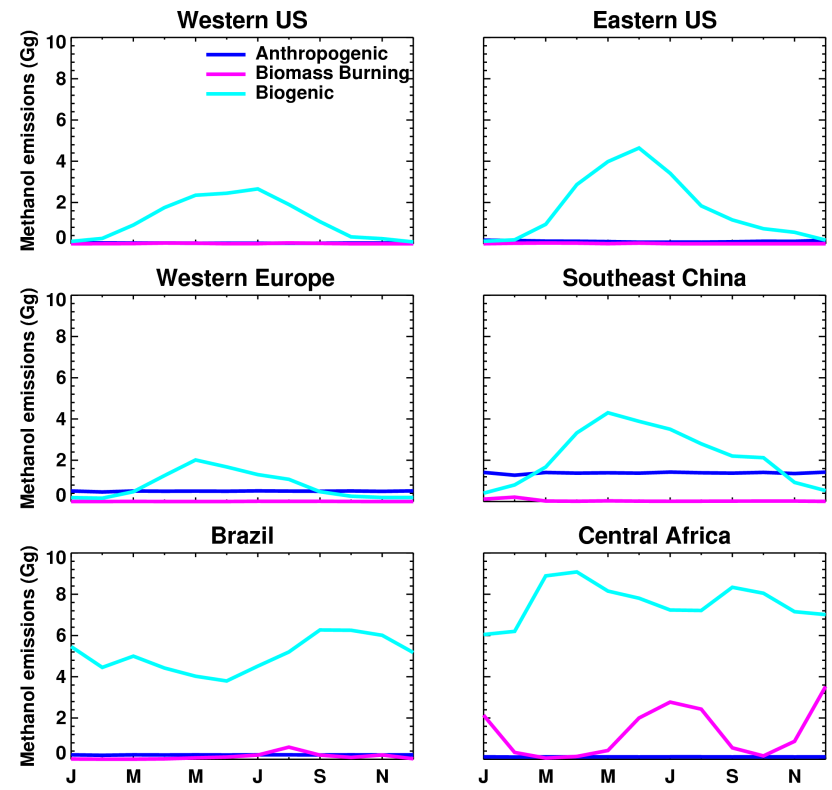

Southeast China

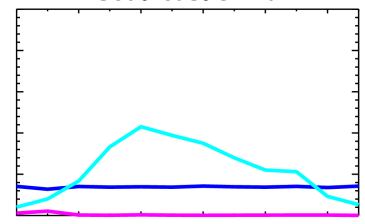

Central Africa

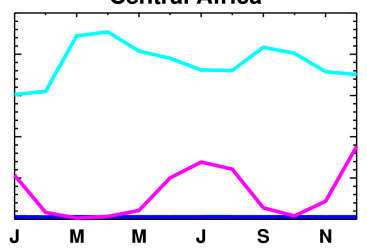

Fig. 11. Seasonality of methanol emissions from anthropogenic (blue), biomass burning (pink), and biogenic sources (cyan) in the GEOS-Chem a priori simulation for the regions in Fig. S4.

Data are shown for June-August, corresponding to the seasonal peak in methanol concentrations in the $\mathrm{NH}$ extratropics, and include all retrievals with DOFS $>0.5$. As we see from Fig. 5, the TES inversion leads to an upward revision of emissions for the western US, eastern US, and Europe, and a downward revision for southeastern China. The methanol: CO slopes are similar for the eastern US and western Europe (0.051-0.052 $\mathrm{ppb} \mathrm{ppb}^{-1}$ ), and both are lower than is observed over the western US $\left(0.073 \mathrm{ppb} \mathrm{ppb}^{-1}\right)$. However, all three values are significantly higher than the enhancement ratios typically associated with anthropogenic emissions ( $\sim 0.012 \mathrm{~mol} \mathrm{~mol}^{-1}$; Goldan et al., 1995; de Gouw et al., 2005; Millet et al., 2005; Warneke et al., 2007), and this is consistent with the predominance of biogenic sources in the model for these regions during summer (Fig. 11). The higher slope over the western US suggests an anomalously large methanol source relative to the amount of co-emitted (or co-located) CO fluxes. The increased a posteriori emissions for this region could thus reflect the presence of plant species that emit large quantities of methanol, or a missing source from agriculture.

Over southeastern China, where the inversion leads to decreased emissions (Fig. 5), the methanol: CO slope is

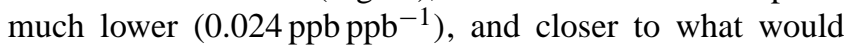
be expected for predominantly anthropogenic emissions. In contrast, the a priori methanol emissions over this region (Fig. 11) are mostly biogenic during the spring and summer months; it thus appears that the biogenic source for this region is overestimated. 

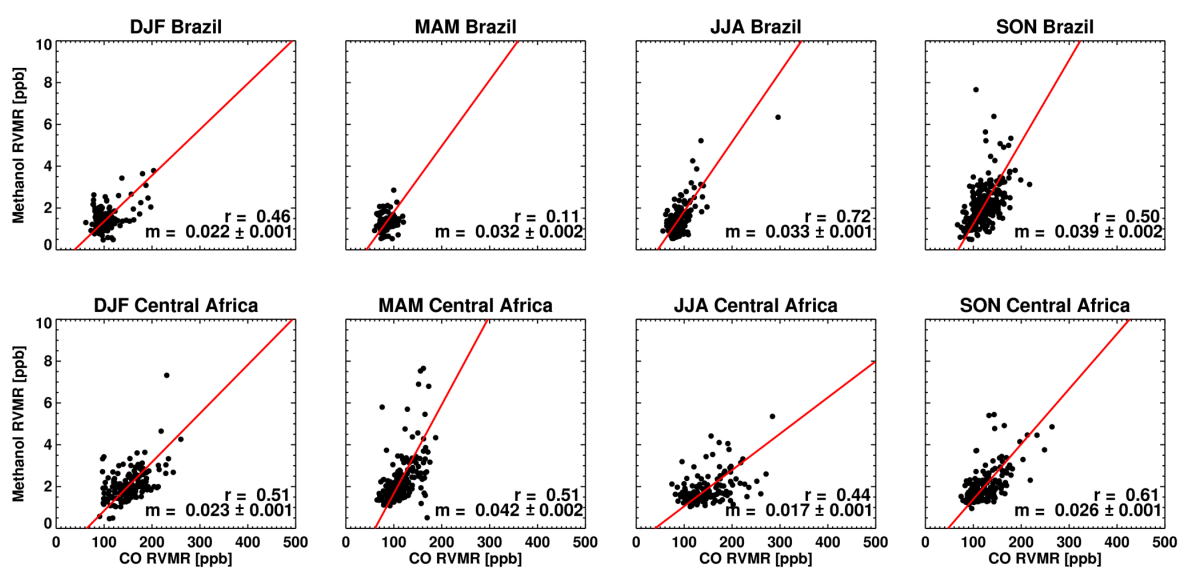

Fig. 12. Tropical methanol: CO correlations as measured by TES. Regions are as outlined in Fig. S4. The TES CO RVMR is calculated by applying the TES methanol RVMR weighting function to the retrieved CO profile. Slopes are calculated using reduced major axis regression.

Figure 12 shows the seasonal progression of methanol: CO correlations measured by TES over Brazil and central Africa, tropical regions where we expect a contribution from both biogenic and pyrogenic sources. Over central Africa we see a distinct seasonal variation in the methanol: CO slopes, with lower values in JJA and DJF (0.017-0.023 $\left.\mathrm{ppb} \mathrm{ppb}^{-1}\right)$ compared to the other seasons (0.026-0.042 $\left.\mathrm{ppb} \mathrm{ppb}^{-1}\right)$. DJF and JJA correspond to the biomass burning seasons for this region (Fig. 11), and the observed slopes are in line with typical methanol: $\mathrm{CO}$ emission ratios for biomass burning (Andreae and Merlet, 2001). Therefore, it appears that biomass burning is a predominant contributor to atmospheric methanol over central Africa during these seasons. On the other hand, the a priori emissions employed in GEOS-Chem (Fig. 11) assume that the biogenic flux is dominant year-round. The a posteriori source reduction for this region, seen in Fig. 5, thus probably reflects an overestimate of biogenic, rather than biomass burning, emissions.

Over Brazil, biomass burning peaks in August-September (Fig. 11) and is not associated with a minimum in the observed methanol:CO slope (Fig. 12). Instead, the slope slowly increases throughout the year. This may simply reflect the seasonality of biogenic emissions, with fire emissions playing a more modest role for this region, which is broadly consistent with the a priori information (Fig. 11).

\section{Impact of methanol on global photochemical production of $\mathrm{CO}$ and $\mathrm{HCHO}$}

Photochemical oxidation of methanol is a source of atmospheric $\mathrm{HCHO}$ and $\mathrm{CO}$, two compounds that play important roles in the chemistry of $\mathrm{OH}$ and ozone (Logan et al., 1981; Crutzen and Zimmermann, 1991), and which serve as useful tracers for estimating anthropogenic, biogenic, and biomass burning emissions of other species (Suntharalingam et al., 2004; Warneke et al., 2007; Barkley et al., 2008; Millet et al., 2008b). Sources of HCHO and CO include primary emissions and secondary production from volatile organic compounds, including methane, isoprene, methanol, and other biogenic and anthropogenic species. In the case of $\mathrm{CO}$, primary and secondary sources are thought to be of globally similar magnitude (Duncan et al., 2007), whereas secondary production is the predominant source of $\mathrm{HCHO}$ (Fortems-Cheiney et al., 2012). In both cases, identifying the key precursors is important for quantitative interpretation of the ambient concentrations. In this section, we apply a fullchemistry GEOS-Chem simulation for 2008 to quantify the global importance of methanol as a source of $\mathrm{CO}$ and $\mathrm{HCHO}$.

Figure 13 shows the total column secondary $\mathrm{CO}$ production for February, April, June, August, October, and December 2008, along with the percent contribution from methanol oxidation. In the optimized simulation, methanol accounts for $\sim 6 \%$ of global $\mathrm{CO}$ and $\mathrm{HCHO}$ production. Methanol is an important source of $\mathrm{CO}$ and $\mathrm{HCHO}$ during spring and early summer in the Northern Hemisphere, when biogenic emissions of methanol are high but isoprene emissions are still fairly low. During April, methanol contributes up to $25 \%$ of the secondary $\mathrm{CO}$ and $\mathrm{HCHO}$ in northern midlatitudes. During June it contributes up to $\sim 50 \%$ of the local $\mathrm{CO}$ and HCHO production in boreal regions, reflecting the later onset of the growing season at higher latitudes. Over the US Upper Midwest, we find that the maximum contribution of methanol to $\mathrm{CO}$ and $\mathrm{HCHO}$ production is $\sim 25 \%$, occurring in June, which is close to the value of $20 \%$ estimated on the basis of tower measurements by Hu et al. (2011). During other months, methanol can contribute up to $10-15 \%$ of secondary $\mathrm{CO}$ and $\mathrm{HCHO}$ production, depending on the region. Over high isoprene emitting areas of the tropics, the fractional contribution of methanol to $\mathrm{CO}$ and $\mathrm{HCHO}$ production is modest $(0-5 \%)$. Downwind over tropical oceans, the contribution increases (10-20\%) due to methanol's longer 


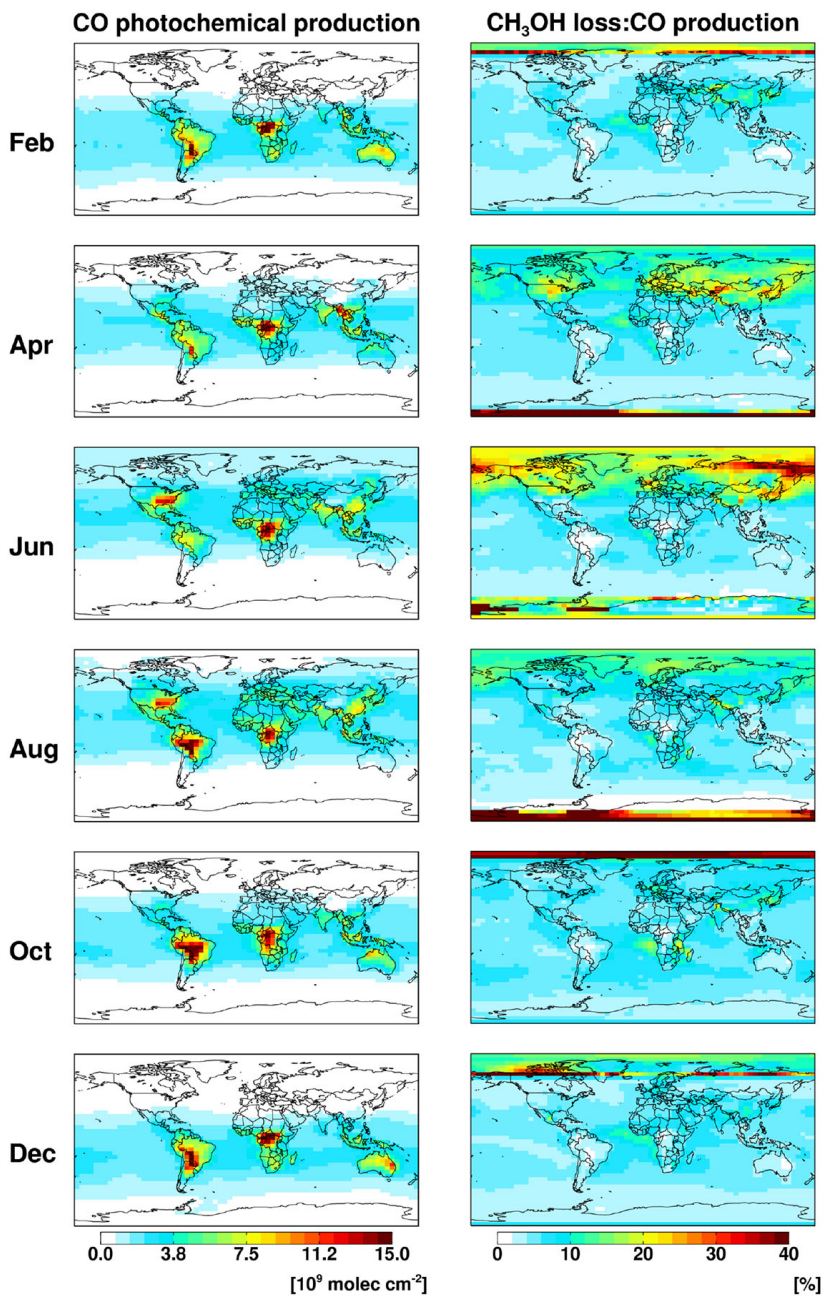

Fig. 13. Importance of methanol as a photochemical precursor of $\mathrm{CO}$ and $\mathrm{HCHO}$. Left column: column-integrated photochemical production of $\mathrm{CO}$. Right column: percent contribution from methanol oxidation in the GEOS-Chem a posteriori simulation for February, April, June, August, October, and December 2008. The fractional contribution to $\mathrm{HCHO}$ production is similar, since almost all photochemical production of $\mathrm{CO}$ goes through $\mathrm{HCHO}$.

lifetime compared to isoprene (several days vs. an hour or less).

\section{Summary and conclusions}

We used two years of new atmospheric methanol observations from the Tropospheric Emission Spectrometer (TES) in an adjoint inversion with the GEOS-Chem CTM to quantify terrestrial emissions of methanol around the globe. A test inversion based on pseudo observations demonstrated that the TES data coverage is sufficient to accurately constrain methanol emissions on regional-to-continental scales. A posteriori uncertainties are reduced significantly compared to the a priori, and are reduced by a factor of two or more through- out most of the northern midlatitudes as well as over East Asia and parts of central Africa and Brazil. Uncertainties are higher over Indonesia/Oceania and high latitude regions, where TES retrievals are limited.

The TES data show that current terrestrial emissions of methanol in GEOS-Chem (driven by a modified implementation of MEGANv2.1 biogenic emissions) are too low, and that the global flux should be increased by $60 \%$ from 76 to $122 \mathrm{Tg} \mathrm{yr}^{-1}$. This optimized source is $\sim 23 \%$ of the estimated global isoprene flux (535 $\mathrm{Tg} \mathrm{yr}^{-1}$; Guenther et al., 2012) and is similar to the combined flux of all anthropogenic volatile organic compounds (estimated at $100-200 \mathrm{Tg} \mathrm{yr}^{-1}$; Müller, 1992; Piccot et al., 1992; van Aardenne et al., 2001). We find that the largest relative increases to the a priori emissions occur over mostly semi-arid regions such as the western US, Mexico, the Iberian Peninsula, the Sahel, and central Asia. The largest absolute emission increases occur over Mexico and western Europe. Emissions are reduced over southeastern China and over central Africa. The optimized emissions lead to a significant improvement in the methanol simulation as compared to an ensemble of aircraft measurements, though discrepancies over the western US point to missing sources in the a priori inventory (and possibly issues with sampling mismatches between the model and the aircraft measurements). Our optimized global terrestrial methanol flux of $122 \mathrm{Tg} \mathrm{yr}^{-1}$ also supports two other recent top-down estimates derived using in situ (Millet et al., 2008a) and space-based (Stavrakou et al., 2011) observations (114-120 $\mathrm{Tg} \mathrm{yr}^{-1}$ ).

We carried out two separate sensitivity tests to assess the degree to which our derived methanol emission fluxes depend on uncertainties in model $\mathrm{OH}$. An inversion that employed $\mathrm{OH}$ concentrations from an alternate model version led to only minor differences $(<10 \%)$ in the a posteriori continental fluxes compared to the baseline analysis. A second sensitivity analysis that employed a parameterization to approximate $\mathrm{OH}$ recycling during isoprene oxidation at low $\mathrm{NO}_{\mathrm{x}}$ indicated that uncertainties in low- $\mathrm{NO}_{\mathrm{x}}$ isoprene chemistry most likely lead to at most a $30 \%$ bias in our computed tropical methanol fluxes.

We also performed sensitivity tests to assess the impact of model errors related to methanol dry deposition and air-sea exchange. Varying the efficiency of reactive uptake generally led to changes of less than $5 \%$ in the regional a posteriori emissions. Likewise, varying the assumed concentration of methanol in the surface ocean by $\pm 41 \%$ also led to a posteriori emission differences of less than $5 \%$ outside of the tropics. In tropical island regions, where terrestrial emissions occur in close proximity to the ocean, emissions varied by about $15 \%$. Global fluxes from all sensitivity runs ranged from 118 to $126 \mathrm{Tg} \mathrm{yr}^{-1}$.

Since our inversion optimized the total terrestrial emission flux and did not attempt to resolve individual sources, we employed the methanol: $\mathrm{CO}$ correlations measured by TES to interpret the a posteriori results and improve our 
understanding of the underlying emission processes. These observations suggest that biogenic methanol emissions are currently underestimated over the US, western Europe, and Brazil in our implementation of MEGANv2.1. Over the western US, the majority of methanol emissions appear to be from sources that do not co-emit $\mathrm{CO}$, suggesting high emissions from plant functional types in this region or missing sources from agriculture. An overestimate of biogenic emissions is apparent over southeastern China and central Africa during June-August, as the corresponding TES methanol: $\mathrm{CO}$ slopes are consistent with a predominant role for anthropogenic and biomass burning emissions, respectively.

The source optimization presented here demonstrates the importance of methanol as a photochemical precursor of $\mathrm{CO}$ and HCHO. Based on a full-chemistry GEOS-Chem simulation, we estimate that methanol contributes $6 \%$ to the global secondary source of $\mathrm{CO}$ and $\mathrm{HCHO}$, and up to $\sim 50 \%$ to local photochemical production of $\mathrm{CO}$ and $\mathrm{HCHO}$ in boreal regions in June, when methanol emissions are elevated but isoprene emissions are low.

Future work involving the full record of methanol observations from TES and other space-based instruments, such as the IASI sensors aboard the MetOp series of satellites and possibly CrIS (Cross-track Infrared Sounder) on NASA's Suomi NPP satellite, should help us to better quantify methanol emissions as a function of plant functional type and phenology. These data may also prove valuable for understanding ecosystem responses to climate variability and for distinguishing sources types for other species measured from space, such as $\mathrm{CO}_{2}, \mathrm{CO}$, and $\mathrm{CH}_{4}$.

\section{Supplementary material related to this article is available online at http://www.atmos-chem-phys.net/14/ 2555/2014/acp-14-2555-2014-supplement.pdf.}

Acknowledgements. This work was supported by NASA through the Atmospheric Chemistry Modeling and Analysis Program (grant no. NNX10AG65G), the University of Minnesota Supercomputing Institute, and by the EPA Science To Achieve Results program (grant no. RD83455901). We gratefully thank J. Worden and M. Luo for their role in developing the TES methanol retrieval.

Edited by: M. Kopacz

\section{References}

Andreae, M. O. and Merlet, P.: Emission of trace gases and aerosols from biomass burning, Global Biogeochem. Cy., 15, 955-966, doi:10.1029/2000GB001382, 2001.

Barkley, M. P., Palmer, P. I., Kuhn, U., Kesselmeier, J., Chance, K., Kurosu, T. P., Martin, R. V., Helmig, D., and Guenther, A.: Net ecosystem fluxes of isoprene over tropical South
America inferred from Global Ozone Monitoring Experiment (GOME) observations of HCHO columns, J. Geophys. Res., 113, doi:10.1029/2008JD009863, 2008.

Beale, R., Dixon, J. L., Arnold, S. R., Liss, P. S., and Nightingale, P. D.: Methanol, acetaldehyde, and acetone in the surface waters of the Atlantic Ocean, J. Geophys. Res.-Oceans, 118, 5412-5425, doi:10.1002/jgrc.20322, 2013.

Beer, R., Glavich, T. A., and Rider, D. M.: Tropospheric emission spectrometer for the Earth Observing System's Aura Satellite, Appl. Optics, 40, 2356-2367, 2001.

Beer, R., Shephard, M. W., Kulawik, S. S., Clough, S. A., Eldering, A., Bowman, K. W., Sander, S. P., Fisher, B. M., Payne, V. H., Luo, M., Osterman, G. B., and Worden, J. R.: First satellite observations of lower tropospheric ammonia and methanol, Geophys. Res. Lett., 35, L09801, doi:10.1029/2008GL033642, 2008.

Bousserez, N., Henze, D. K., Perkins, A., Bowman, K. W., Lee, M., Liu, J., Deng, F., and Jones, D. B. A.: Improved analysis error covariance matrix estimates for variational inverse problems, Q. J. Roy. Meteor. Soc., submitted, 2013.

Brock, C. A., Cozic, J., Bahreini, R., Froyd, K. D., Middlebrook, A. M., McComiskey, A., Brioude, J., Cooper, O. R., Stohl, A., Aikin, K. C., de Gouw, J. A., Fahey, D. W., Ferrare, R. A., Gao, R.-S., Gore, W., Holloway, J. S., Hübler, G., Jefferson, A., Lack, D. A., Lance, S., Moore, R. H., Murphy, D. M., Nenes, A., Novelli, P. C., Nowak, J. B., Ogren, J. A., Peischl, J., Pierce, R. B., Pilewskie, P., Quinn, P. K., Ryerson, T. B., Schmidt, K. S., Schwarz, J. P., Sodemann, H., Spackman, J. R., Stark, H., Thomson, D. S., Thornberry, T., Veres, P., Watts, L. A., Warneke, C., and Wollny, A. G.: Characteristics, sources, and transport of aerosols measured in spring 2008 during the aerosol, radiation, and cloud processes affecting Arctic Climate (ARCPAC) Project, Atmos. Chem. Phys., 11, 2423-2453, doi:10.5194/acp-11-24232011, 2011.

Byrd, R. H., Lu, P. H., Nocedal, J., and Zhu, C. Y.: A limited memory algorithm for bound constrained optimization, SIAM J. Sci. Comput., 16, 1190-1208, doi:10.1137/0916069, 1995.

Cady-Pereira, K. E., Shephard, M. W., Millet, D. B., Luo, M., Wells, K. C., Xiao, Y., Payne, V. H., and Worden, J.: Methanol from TES global observations: retrieval algorithm and seasonal and spatial variability, Atmos. Chem. Phys., 12, 8189-8203, doi:10.5194/acp-12-8189-2012, 2012.

Carpenter, L. J., Lewis, A. C., Hopkins, J. R., Read, K. A., Longley, I. D., and Gallagher, M. W.: Uptake of methanol to the North Atlantic Ocean surface, Global Biogeochem. Cy., 18, GB4027, doi:10.1029/2004GB002294, 2004.

Choi, W., Faloona, I. C., Bouvier-Brown, N. C., McKay, M., Goldstein, A. H., Mao, J., Brune, W. H., LaFranchi, B. W., Cohen, R. C., Wolfe, G. M., Thornton, J. A., Sonnenfroh, D. M., and Millet, D. B.: Observations of elevated formaldehyde over a forest canopy suggest missing sources from rapid oxidation of arboreal hydrocarbons, Atmos. Chem. Phys., 10, 8761-8781, doi:10.5194/acp-10-8761-2010, 2010

Crutzen, P. J. and Zimmermann, P. H.: The changing photochemistry of the troposphere, Tellus A, 43, 136-151, 1991.

de Gouw, J. A., Middlebrook, A. M., Warneke, C., Goldan, P. D., Kuster, W. C., Roberts, J. M., Fehsenfeld, F. C., Worsnop, D. R., Canagaratna, M. R., Pszenny, A. A. P., Keene, W. C., Marchewka, M., Bertman, S. B., and Bates, T. S.: Budget of organic carbon in a polluted atmosphere: results from the New Eng- 
land Air Quality Study in 2002, J. Geophys. Res., 110, D16305, doi:10.1029/2004JD005623, 2005.

Duncan, B. N., Logan, J. A., Bey, I., Megretskaia, I. A., Yantosca, R. M., Novelli, P. C., Jones, N. B., and Rinsland, C. P.: Global budget of CO, 1988-1997: source estimates and validation with a global model, J. Geophys. Res., 112, D22301, doi:10.1029/2007JD008459, 2007.

Fall, R.: Abundant oxygenates in the atmosphere: A biochemical perspective, Chem. Rev., 103, 4941-4951, doi:10.1021/cr0206521, 2003.

Fall, R. and Benson, A. A.: Leaf methanol - The simplest natural product from plants, Trends Plant Sci., 1, 296-301, doi:10.1016/S1360-1385(96)88175-0, 1996.

Fehsenfeld, F. C., Ancellet, G., Bates, T. S., Goldstein, A. H., Hardesty, R. M., Honrath, R., Law, K. S., Lewis, A. C., Leaitch, R., McKeen, S., Meagher, J., Parrish, D. D., Pszenny, A. A. P., Russell, P. B., Schlager, H., Seinfeld, J., Talbot, R., and Zbinden, R.: International Consortium for Atmospheric Research on Transport and Transformation (ICARTT): North America to Europe Overview of the 2004 summer field study, J. Geophys. Res., 111, D23S01, doi:10.1029/2006JD007829, 2006

Fortems-Cheiney, A., Chevallier, F., Pison, I., Bousquet, P., Saunois, M., Szopa, S., Cressot, C., Kurosu, T. P., Chance, K., and Fried, A.: The formaldehyde budget as seen by a global-scale multiconstraint and multi-species inversion system, Atmos. Chem. Phys., 12, 6699-6721, doi:10.5194/acp-12-6699-2012, 2012.

Galbally, I. E. and Kirstine, W.: The production of methanol by flowering plants and the global cycle of methanol, J. Atmos. Chem., 43, 195-229, 2002.

Goldan, P. D., Trainer, M., Kuster, W. C., Parrish, D. D., Carpenter, J., Roberts, J. M., Yee, J. E., and Fehsenfeld, F. C.: Measurements of hydrocarbons, oxygenated hydrocarbons, carbon monoxide, and nitrogen oxides in an urban basin in Colorado: implications for emission inventories, J. Geophys. Res., 100, 22771-22783, 1995.

Guenther, A. B., Jiang, X., Heald, C. L., Sakulyanontvittaya, T., Duhl, T., Emmons, L. K., and Wang, X.: The Model of Emissions of Gases and Aerosols from Nature version 2.1 (MEGAN2.1): an extended and updated framework for modeling biogenic emissions, Geosci. Model Dev., 5, 1471-1492, doi:10.5194/gmd-51471-2012, 2012.

Hansen, P. C.: Rank-Deficient and Discrete Ill-Posed Problems: Numerical Aspects of Linear Inversion, SIAM, Society for Industrial and Applied Mathematics, Philadelphia, USA, 1998.

Heikes, B. G., Chang, W. N., Pilson, M. E. Q., Swift, E., Singh, H. B, Guenther, A., Jacob, D. J., Field, B. D., Fall, R., Riemer, D., and Brand, L.: Atmospheric methanol budget and ocean implication, Global Biogeochem. Cy., 16, 1133, doi:10.1029/2002GB001895, 2002.

Henze, D. K., Seinfeld, J. H., and Shindell, D. T.: Inverse modeling and mapping US air quality influences of inorganic $\mathrm{PM}_{2.5}$ precursor emissions using the adjoint of GEOS-Chem, Atmos. Chem. Phys., 9, 5877-5903, doi:10.5194/acp-9-5877-2009, 2009.

Holzinger, R., Warneke, C., Hansel, A., Jordan, A., Lindinger, W., Scharffe, D. H., Schade, G., and Crutzen, P. J.: Biomass burning as a source of formaldehyde, acetaldehyde, methanol, acetone, acetonitrile, and hydrogen cyanide, Geophys. Res. Lett., 26, 1161-1164, 1999.
Howard, C. J., Kumar, A., Malkina, I., Mitloehner, F., Green, P. G., Flocchini, R. G., and Kleeman, M. J.: Reactive organic gas emissions from livestock feed contribute significantly to ozone production in Central California, Environ. Sci. Technol., 44, 23092314, doi:10.1021/es902864u, 2010.

Hu, L., Millet, D. B., Mohr, M. J., Wells, K. C., Griffis, T. J., and Helmig, D.: Sources and seasonality of atmospheric methanol based on tall tower measurements in the US Upper Midwest, Atmos. Chem. Phys., 11, 11145-11156, doi:10.5194/acp-1111145-2011, 2011.

Jacob, D. J., Crawford, J. H., Maring, H., Clarke, A. D., Dibb, J. E., Emmons, L. K., Ferrare, R. A., Hostetler, C. A., Russell, P. B., Singh, H. B., Thompson, A. M., Shaw, G. E., McCauley, E., Pederson, J. R., and Fisher, J. A.: The Arctic Research of the Composition of the Troposphere from Aircraft and Satellites (ARCTAS) mission: design, execution, and first results, Atmos. Chem. Phys., 10, 5191-5212, doi:10.5194/acp-10-5191-2010, 2010.

Jiang, Z., Jones, D. B. A., Kopacz, M., Liu, J., Henze, D. K., and Heald, C.: Quantifying the impact of model errors on top-down estimates of carbon monoxide emissions using satellite observations, J. Geophys. Res., 116, D15306, doi:10.1029/2010JD015282, 2011.

Jiang, Z., Jones, D. B. A., Worden, H. M., Deeter, M. N., Henze, D. K., Worden, J., and Bowman, K. W., Brenninkmeijer, C. A. M., and Schuck, T. J.: Impact of model errors in convective transport on CO source estimates inferred from MOPITT CO retrievals, J. Geophys. Res., 118, 2073-2083, doi:10.1002/jgrd.50216, 2013.

Johnson, M. T.: A numerical scheme to calculate temperature and salinity dependent air-water transfer velocities for any gas, Ocean Sci., 6, 913-932, doi:10.5194/os-6-913-2010, 2010.

Karl, T., Harley, P., Emmons, L., Thornton, B., Guenther, A., Basu, C., Turnipseed, A., and Jardine, K.: Efficient atmospheric cleansing of oxidized organic trace gases by vegetation, Science, 330, 816-819, doi:10.1126/science.1192534, 2010.

Kopacz, M., Jacob, D. J., Henze, D. K., Heald, C. L., Streets, D. G., and Zhang, Q.: Comparison of adjoint and analytical Bayesian inversion methods for constraining Asian sources of carbon monoxide using satellite (MOPITT) measurements of CO columns, J. Geophys. Res., 114, D04305, doi:10.1029/2007JD009264, 2009.

Kopacz, M., Jacob, D. J., Fisher, J. A., Logan, J. A., Zhang, L., Megretskaia, I. A., Yantosca, R. M., Singh, K., Henze, D. K., Burrows, J. P., Buchwitz, M., Khlystova, I., McMillan, W. W., Gille, J. C., Edwards, D. P., Eldering, A., Thouret, V., and Nedelec, P.: Global estimates of CO sources with high resolution by adjoint inversion of multiple satellite datasets (MOPITT, AIRS, SCIAMACHY, TES), Atmos. Chem. Phys., 10, 855-876, doi:10.5194/acp-10-855-2010, 2010.

Kopacz, M., Mauzerall, D. L., Wang, J., Leibensperger, E. M., Henze, D. K., and Singh, K.: Origin and radiative forcing of black carbon transported to the Himalayas and Tibetan Plateau, Atmos. Chem. Phys., 11, 2837-2852, doi:10.5194/acp-11-28372011, 2011.

Kubistin, D., Harder, H., Martinez, M., Rudolf, M., Sander, R., Bozem, H., Eerdekens, G., Fischer, H., Gurk, C., Klüpfel, T., Königstedt, R., Parchatka, U., Schiller, C. L., Stickler, A., Taraborrelli, D., Williams, J., and Lelieveld, J.: Hydroxyl radicals in the tropical troposphere over the Suriname rainforest: comparison of measurements with the box model MECCA, At- 
mos. Chem. Phys., 10, 9705-9728, doi:10.5194/acp-10-97052010, 2010

Lelieveld, J., Butler, T. M., Crowley, J. N., Dillon, T. J., Fischer, H., Ganzeveld, L., Harder, H., Lawrence, M. G., Martinez, M., Taraborrelli, D., and Williams, J.: Atmospheric oxidation capacity sustained by a tropical forest, Nature, 452, 737-740, doi:10.1038/nature06870, 2008.

Lewis, A. C., Hopkins, J. R., Carpenter, L. J., Stanton, J., Read, K. A., and Pilling, M. J.: Sources and sinks of acetone, methanol, and acetaldehyde in North Atlantic marine air, Atmos. Chem. Phys., 5, 1963-1974, doi:10.5194/acp-5-1963-2005, 2005.

Logan, J. A., Prather, M. J., Wofsy, S. C., and McElroy, M. B.: Tropospheric chemistry - A global perspective, J. Geophys. Res., 86, 7210-7254, 1981.

Malkina, I. L., Kumar, A., Green, P. G., and Mitloehner, F. M.: Identification and quantitation of volatile organic compounds emitted from dairy silages and other feedstuffs, J. Environ. Qual., 40, 2836, doi:10.2134/jeq2010.0302, 2011.

Mao, J., Ren, X., Zhang, L., Van Duin, D. M., Cohen, R. C., Park, J.-H., Goldstein, A. H., Paulot, F., Beaver, M. R., Crounse, J. D., Wennberg, P. O., DiGangi, J. P., Henry, S. B., Keutsch, F. N., Park, C., Schade, G. W., Wolfe, G. M., Thornton, J. A., and Brune, W. H.: Insights into hydroxyl measurements and atmospheric oxidation in a California forest, Atmos. Chem. Phys., 12, 8009-8020, doi:10.5194/acp-12-8009-2012, 2012.

Millet, D. B., Donahue, N. M., Pandis, S. N., Polidori, A., Stanier, C. O., Turpin, B. J., and Goldstein, A. H.: Atmospheric volatile organic compound measurements during the Pittsburgh Air Quality Study: Results, interpretation, and quantification of primary and secondary contributions, J. Geophys. Res., 110, D07S07, doi:10.1029/2004JD004601, 2005.

Millet, D. B., Jacob, D. J., Turquety, S., Hudman, R. C., Wu, S., Fried, A., Walega, J., Heikes, B. G., Blake, D. R., Singh, H. B., Anderson, B. E., and Clarke, A. D.: Formaldehyde distribution over North America: implications for satellite retrievals of formaldehyde columns and isoprene emission, J. Geophys. Res., 111, D24S02, doi:10.1029/2005JD006853, 2006.

Millet, D. B., Jacob, D. J., Custer, T. G., de Gouw, J. A., Goldstein, A. H., Karl, T., Singh, H. B., Sive, B. C., Talbot, R. W., Warneke, C., and Williams, J.: New constraints on terrestrial and oceanic sources of atmospheric methanol, Atmos. Chem. Phys., 8, 68876905, doi:10.5194/acp-8-6887-2008, 2008a.

Millet, D. B., Jacob, D. J., Boersma, K. F., Fu, T. M., Kurosu, T. P., Chance, K., Heald, C. L., and Guenther, A.: Spatial distribution of isoprene emissions from North America derived from formaldehyde column measurements by the OMI satellite sensor, J. Geophys. Res., 113, D02307, doi:10.1029/2007JD008950, 2008b.

Millet, D. B., Apel, E., Henze, D. K., Hill, J., Marshall, J. D., Singh, H. B., and Tessum, C. W.: Natural and anthropogenic ethanol sources in North America and potential atmospheric impacts of ethanol fuel use, Environ. Sci. Technol., 46, 8484-8492, doi:10.1021/es300162u, 2012.

Müller, J. F.: Geographical distribution and seasonal variation of surface emissions and deposition velocities of atmospheric trace gases, J. Geophys. Res., 97, 3787-3804, 1992.

Nightingale, P. D., Malin, G., Law, C. S., Watson, A. J., Liss, P. S., Liddicoat, M. I., Boutin, J., and Upstill-Goddard, R. C.: In situ evaluation of air-sea gas exchange parameterizations using novel conservative and volatile tracers, Global Biogeochem. Cy., 14, 373-387, doi:10.1029/1999GB900091, 2000.

Parrington, M., Palmer, P. I., Henze, D. K., Tarasick, D. W., Hyer, E. J., Owen, R. C., Helmig, D., Clerbaux, C., Bowman, K. W., Deeter, M. N., Barratt, E. M., Coheur, P.-F., Hurtmans, D., Jiang, Z., George, M., and Worden, J. R.: The influence of boreal biomass burning emissions on the distribution of tropospheric ozone over North America and the North Atlantic during 2010, Atmos. Chem. Phys., 12, 2077-2098, doi:10.5194/acp-12-20772012, 2012.

Parrish, D. D., Kondo, Y., Cooper, O. R., Brock, C. A., Jaffe, D. A., Trainer, M., Ogawa, T., Hubler, G., and Fehsenfeld, F. C.: Intercontinental Transport and Chemical Transformation 2002 (ITCT 2K2) and Pacific Exploration of Asian Continental Emission (PEACE) experiments: An overview of the 2002 winter and spring intensives, J. Geophys. Res., 109, D23S01, doi:10.1029/2004JD004980, 2004.

Parrish, D. D., Allen, D. T., Bates, T. S., Estes, M., Fehsenfeld, F. C., Feingold, G., Ferrare, R., Hardesty, R. M., Meagher, J. F., Nielsen-Gammon, J. W., Pierce, R. B., Ryerson, T. B., Seinfeld, J. H., and Williams, E. J.: Overview of the Second Texas Air Quality Study (TexAQS II) and the Gulf of Mexico Atmospheric Composition and Climate Study (GoMACCS), J. Geophys. Res., 114, D00F13, doi:10.1029/2009JD011842, 2009.

Piccot, S. D., Watson, J. J., and Jones, J. W.: A global inventory of volatile organic compoud emissions from anthropogenic sources, J. Geophys. Res., 97, 9897-9912, 1992.

Pugh, T. A. M., MacKenzie, A. R., Hewitt, C. N., Langford, B., Edwards, P. M., Furneaux, K. L., Heard, D. E., Hopkins, J. R., Jones, C. E., Karunaharan, A., Lee, J., Mills, G., Misztal, P., Moller, S., Monks, P. S., and Whalley, L. K.: Simulating atmospheric composition over a South-East Asian tropical rainforest: performance of a chemistry box model, Atmos. Chem. Phys., 10, 279-298, doi:10.5194/acp-10-279-2010, 2010.

Rodgers, C. D.: Inverse Methods for Atmospheric Sounding: Theory and Practice, World Scientific, Tokyo, 2000.

Shephard, M. W., Cady-Pereira, K. E., Luo, M., Henze, D. K., Pinder, R. W., Walker, J. T., Rinsland, C. P., Bash, J. O., Zhu, L., Payne, V. H., and Clarisse, L.: TES ammonia retrieval strategy and global observations of the spatial and seasonal variability of ammonia, Atmos. Chem. Phys., 11, 10743-10763, doi:10.5194/acp-11-10743-2011, 2011.

Singh, H. B, Kanakidou, M., Crutzen, P. J., and Jacob, D. J.: High concentrations and photochemical fate of oxygenated hydrocarbons in the global troposphere, Nature, 378, 50-54, 1995.

Singh, H. B, Chen, Y., Staudt, A., Jacob, D., Blake, D., Heikes, B., and Snow, J.: Evidence from the Pacific troposphere for large global sources of oxygenated organic compounds, Nature, 410, 1078-1081, 2001.

Singh, H. B., Brune, W. H., Crawford, J. H., Flocke, F., and Jacob, D. J.: Chemistry and transport of pollution over the Gulf of Mexico and the Pacific: spring 2006 INTEX-B campaign overview and first results, Atmos. Chem. Phys., 9, 2301-2318, doi:10.5194/acp-9-2301-2009, 2009.

Singh, K., Jardak, M., Sandu, A., Bowman, K., Lee, M., and Jones, D.: Construction of non-diagonal background error covariance matrices for global chemical data assimilation, Geosci. Model Dev., 4, 299-316, doi:10.5194/gmd-4-299-2011, 2011. 
Stavrakou, T., Guenther, A., Razavi, A., Clarisse, L., Clerbaux, C., Coheur, P.-F., Hurtmans, D., Karagulian, F., De Mazière, M., Vigouroux, C., Amelynck, C., Schoon, N., Laffineur, Q., Heinesch, B., Aubinet, M., Rinsland, C., and Müller, J.-F.: First space-based derivation of the global atmospheric methanol emission fluxes, Atmos. Chem. Phys., 11, 4873-4898, doi:10.5194/acp-11-4873-2011, 2011.

Stone, D., Evans, M. J., Edwards, P. M., Commane, R., Ingham, T., Rickard, A. R., Brookes, D. M., Hopkins, J., Leigh, R. J., Lewis, A. C., Monks, P. S., Oram, D., Reeves, C. E., Stewart, D., and Heard, D. E.: Isoprene oxidation mechanisms: measurements and modelling of $\mathrm{OH}$ and $\mathrm{HO}_{2}$ over a South-East Asian tropical rainforest during the OP3 field campaign, Atmos. Chem. Phys., 11, 6749-6771, doi:10.5194/acp-11-6749-2011, 2011.

Suntharalingam, P., Jacob, D. J., Palmer, P. I., Logan, J. A., Yantosca, R. M., Xiao, Y. P., Evans, M. J., Streets, D. G., Vay, S. L., and Sachse, G. W.: Improved quantification of Chinese carbon fluxes using $\mathrm{CO}_{2} / \mathrm{CO}$ correlations in Asian outflow, J. Geophys. Res., 109, D18S18, doi:10.1029/2003JD004362, 2004.

Tie, X., Guenther, A., and Holland, E.: Biogenic methanol and its impacts on tropospheric oxidants, Geophys. Res. Lett., 30, 1881, doi:10.1029/2003GL017167, 2003.

Tyndall, G. S., Cox, R. A., Granier, C., Lesclaux, R., Moortgat, G. K., Pilling, M. J., Ravishankara, A. R., and Wallington, T. J.: Atmospheric chemistry of small organic peroxy radicals, J. Geophys. Res., 106, 12157-12182, 2001.

van Aardenne, J. A., Dentener, F. J., Olivier, J. G. J., Goldewijk, C., and Lelieveld, J.: A 1 degrees $\times 1$ degrees resolution data set of historical anthropogenic trace gas emissions for the period 1890-1990, Global Biogeochem. Cy., 15, 909-928, doi:10.1029/2000GB001265, 2001.

van der Werf, G. R., Randerson, J. T., Giglio, L., Collatz, G. J., Mu, M., Kasibhatla, P. S., Morton, D. C., DeFries, R. S., Jin, Y., and van Leeuwen, T. T.: Global fire emissions and the contribution of deforestation, savanna, forest, agricultural, and peat fires (19972009), Atmos. Chem. Phys., 10, 11707-11735, doi:10.5194/acp10-11707-2010, 2010.

Wang, J., Xu, X., Henze, D. K., Zeng, J., Ji, Q., Tsay, S.-C., and Huang, J., Top-down estimate of dust emissions through integration of MODIS and MISR aerosol retrievals with the GEOS-Chem adjoint model, Geophys. Res. Lett., 39, L08802, doi:10.1029/2012GL051136, 2012.
Warneke, C., McKeen, S. A., de Gouw, J. A., Goldan, P. D., Kuster, W. C., Holloway, J. S., Williams, E. J., Lerner, B. M., Parrish, D. D., Trainer, M., Fehsenfeld, F. C., Kato, S., Atlas, E. L., Baker, A., and Blake, D. R.: Determination of urban volatile organic compound emission ratios and comparison with an emissions database, J. Geophys. Res., 112, D10S47, doi:10.1029/2006JD007930, 2007.

Warneke, C., de Gouw, J. A., Holloway, J. S., Peischl, J., Ryerson, T. B., Atlas, E. L., and Blake, D. R.: Airborne measurements of volatile organic compounds in the Los Angeles Basin and the Central Valley, Abstract A12A-01 presented at 2010 Fall Meeting, AGU, San Francisco, California, 13-17 December, 2010.

Wells, K. C., Millet, D. B., Hu, L., Cady-Pereira, K. E., Xiao, Y., Shephard, M. W., Clerbaux, C. L., Clarisse, L., Coheur, P.F., Apel, E. C., de Gouw, J., Warneke, C., Singh, H. B., Goldstein, A. H., and Sive, B. C.: Tropospheric methanol observations from space: retrieval evaluation and constraints on the seasonality of biogenic emissions, Atmos. Chem. Phys., 12, 5897-5912, doi:10.5194/acp-12-5897-2012, 2012.

Williams, J., Holzinger, R., Gros, V., Xu, X., Atlas, E., and Wallace, D. W. R.: Measurements of organic species in air and seawater from the tropical Atlantic, Geophys. Res. Lett., 31, L23S06, doi:10.1029/2004GL020012, 2004.

Yang, M., Nightingale, P. D., Beale, R., Liss, P. S., Blomquist, B., and Fairall, C.: Atmospheric deposition of methanol over the Atlantic Ocean, P. Natl. Acad. Sci. USA, 110, 20034-20039, doi:10.1073/pnas.1317840110, 2013.

Yang, W., Shabanov, N. V., Huang, D., Wang, W., Dickinson, R. E., Nemani, R. R., Knyazikhin, Y., and Myneni, R. B.: Analysis of leaf area index products from combination of MODIS Terra and Aqua data, Remote Sens. Environ., 104, 297-312, 2006.

Zhang, L., Jacob, D. J., Kopacz, M., Henze, D. K., Singh, K., and Jaffe, D. A.: Intercontinental source attribution of ozone pollution at western US sites using an adjoint method, Geophys. Res. Lett., 36, L11810, doi:10.1029/2009GL037950, 2009.

Zhu, C., Byrd, R. H., Lu, P., and Nocedal, J.: L-BFGS-B: a limited memory FORTRAN code for solving bound constrained optimization problems, Tech. rep., Northwestern University, 1994.

Zhu, L., Henze, D. K., Cady-Pereira, K. E., Shephard, M. W., Luo, M., Pinder, R. W., Bash, J. O., and Jeong, G.-R.: Constraining U.S. ammonia emissions using TES remote sensing observations and the GEOS-Chem adjoint model, J. Geophys. Res.-Atmos., 118, 3355-3368, doi:10.1002/jgrd.50166, 2013. 